\title{
The Effect of Trans Fatty Acids on Human Health: Regulation and Consumption Patterns
}

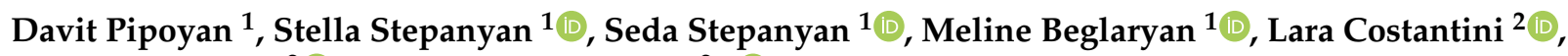 \\ Romina Molinari ${ }^{2} \mathbb{D}$ and Nicolò Merendino ${ }^{2, * \mathbb{B}}$ \\ 1 Center for Ecological-Noosphere Studies of NAS RA, Abovyan 68, Yerevan 0025, Armenia; \\ david.pipoyan@cens.am (D.P.); stella.stepanyan96@gmail.com (S.S.); seda.stepanyan@cens.am (S.S.); \\ meline.beglaryan@cens.am (M.B.) \\ 2 Department of Ecological and Biological Sciences (DEB), Tuscia University, Largo dell'Università snc, \\ 01100 Viterbo, Italy; lara.cost@unitus.it (L.C.); rominamolinari@libero.it (R.M.) \\ * Correspondence: merendin@unitus.it; Tel.: +39-761-357133
}

check for updates

Citation: Pipoyan, D.; Stepanyan, S.; Stepanyan, S.; Beglaryan, M.; Costantini, L.; Molinari, R.; Merendino, N. The Effect of Trans Fatty Acids on Human Health: Regulation and Consumption Patterns. Foods 2021, 10, 2452. https://doi.org/10.3390/foods 10102452

Academic Editors: Kazuo Miyashita

Received: 29 September 2021

Accepted: 12 October 2021

Published: 14 October 2021

Publisher's Note: MDPI stays neutral with regard to jurisdictional claims in published maps and institutional affiliations.

Copyright: (c) 2021 by the authors. Licensee MDPI, Basel, Switzerland. This article is an open access article distributed under the terms and conditions of the Creative Commons Attribution (CC BY) license (https:/ / creativecommons.org/licenses/by/ $4.0 /)$.

\begin{abstract}
Health effects of trans fatty acids (TFAs) on human organisms can vary according to their type, structure, composition, and origin. Even though the adverse health effects of industrial TFAs (iTFAs) have been widely discussed, the health effects of natural TFAs (nTFAs) are still questionable. Hence, it is important to review the literature and provide an overall picture on the health effects of different TFAs coming from industrial and ruminant sources, underlining those types that have adverse health effects as well as suggesting methods for reducing their harmful effects. Multiple databases (PubMed, Medline, Cochrane Library, etc.) were searched with the key words "trans fatty acid sources", "ruminant", "industrial", "conjugated trans linoleic acid", "human", "coronary heart disease", "cancer", etc. Reference lists of the studies were scanned discussing the health effects of iTFAs and nTFAs. The review of the literature showed that iTFAs are found to be more harmful than ruminant-produced nTFAs. Although several beneficial effects (such as reduced risk of diabetes) for nTFAs have been observed, they should be used with caution. Since during labeling it is usually not mentioned whether the TFAs contained in food are of industrial or natural origin, the general suggestion is to reduce their consumption.
\end{abstract}

Keywords: trans fatty acids; human; ruminal; industrial; gut microbiota

\section{Introduction}

Dietary fats, including TFAs, have been one of the central topics of discussion in scientific literature and have received more attention from health professionals and the public than any other nutrients in the food supply [1]. TFAs are unsaturated fatty acids containing at least one double bond in its trans configuration [2]. Trans fat is the final product of a chemical process called partial hydrogenation of cis-unsaturated fatty acids.

Even though there is a slight difference in the geometry of the carbon chain, the chemical structure of TFAs is similar to that of saturated fatty acids (SFAs). The question is whether this geometric difference leads to a difference in health effects. The impact of SFAs on human health has been widely discussed in the literature [3-6], while there is no definite answer on whether TFAs have a negative or positive health effects, as it is highly dependent on their source, type, and transformations they undergo in the organism. It has been shown by randomized controlled trials that, in general, replacing dietary SFAs with unsaturated fatty acids improves cardiovascular health [4]. However, when discussing the health effects of unsaturated fatty acids, an important distinction should be made between its different types, especially TFAs. The health influence of different types of trans fats shall be discussed separately, as they might not only be different, but actually contrasting.

Overall, there are four main sources of TFAs in the human diet; industrially produced TFAs by partial hydrogenation of vegetable oils, TFAs produced during heat processes, 
TFAs occurring naturally in ruminant sources, as well as TFAs synthesized for utilization as dietary supplements [7]. TFAs are classified according to the two main sources they come from, "industrial" and "natural". Industrial or artificial TFAs are produced during manufacturing by partial hydrogenation of liquid vegetable or fish oils containing unsaturated fatty acids. On the other hand, nTFAs are produced in the rumen of ruminant animals like cows, sheep, and goats by bacterial transformation of unsaturated fatty acids derived from feed. A small amount of TFAs is also present in poultry and pork fat [8-10].

During the reaction of partial hydrogenation, the unsaturated fat is transformed to trans fat, as some of the cis double bonds are converted into trans-double bonds by isomerization reaction. While artificial TFAs are generated through partial hydrogenation with hydrogen gas and a metal catalyst, nTFAs arise through partial hydrogenation with hydrogen produced during oxidation of substrates and bacterial enzymes as catalysts [11,12].

Generally, ruminant animal origin foods contain low quantities of nTFAs and high levels in the diets mainly come from iTFA [13-15]. nTFAs are found in animal products like milk, butter, cheese, and beef [12]. Artificial TFAs are eventually found in spreads like margarine, cooking fats for deep frying, and shortening for baking, as well as some popular processed and frozen foods like microwave popcorn, frozen pizza, and snack foods. Huang et al. mentioned that bread and bakery products, cereal and grain products, and confectionery are the top three food groups that contain specific ingredients indicative of iTFA [14]. It is important to note that some TFAs are also formed during the frying of oils at high temperatures. According to Chen et al., the previous studies indicated that several factors including frying conditions, the fatty acid composition, and coexisted antioxidants in frying materials would contribute to the variation in the thermal TFAs accumulation [16].

Both iTFAs and rTFAs consist of the same positional trans isomers, but they differ in distribution and amount [13]. iTFAs contain trans isomers of oleic acid (C18:1 cis-9), the major one being elaidic acid (C18:1 trans-9). In contrast to this, the predominant nTFA in milk and meat is vaccenic acid (VA) (C18:1 trans-11) [17]. In addition, ruminant fat contains small amounts of conjugated linoleic acid (CLA) isomers (C18:2 cis-9, C18:2 trans-11) [18]. Chemical structures of fatty acids are presented in Figure 1 [17].

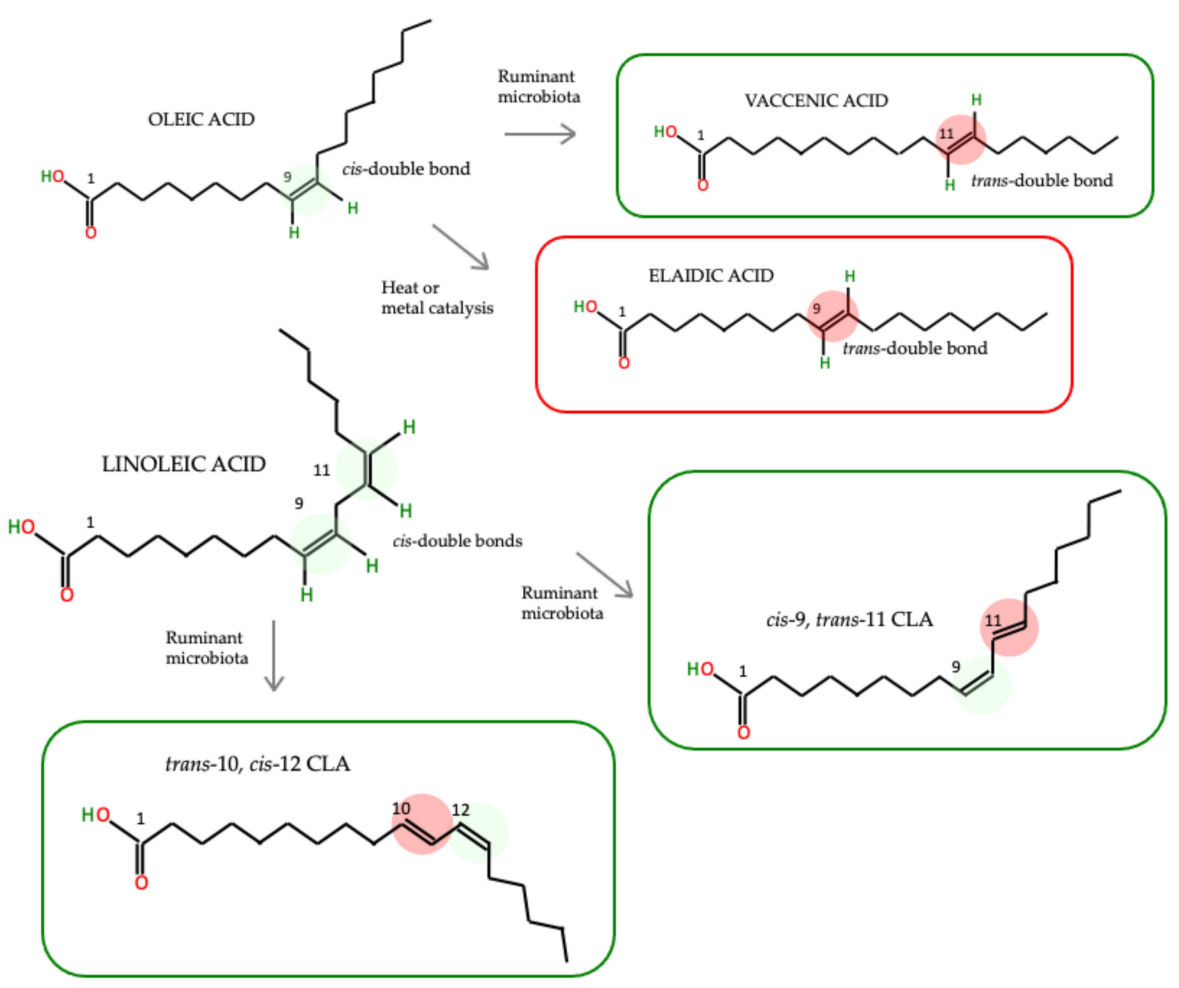

Figure 1. Chemical structure of the major TFA in the green box are nTFA; the red box is iTFA. Green highlighting: cis-double bonds; red highlighting: trans-double bonds. 
The health effects of TFAs are very different and highly debated. iTFAs raise LDL (low-density lipoprotein) cholesterol levels and lower HDL (high-density lipoprotein) cholesterol levels, consequently, increasing the risk of coronary heart disease [19]. Moreover, it has been found that consumption of iTFAs increases the risk of atherosclerosis and that TFAs induce apoptosis and inflammation [20]. However, some beneficial effects of TFAs have also been discussed, such as the anticancer properties of animal-origin CLA as well as its ability to fight inflammation and reduce the risk of cardiovascular disease [21,22]. Indeed, in the systematic evaluation of Fuke and Nornberg, CLAs have a potential to be used as functional ingredients for the prevention and control of several chronic metabolic disorders [23]. Nevertheless, in the comprehensive review by Benjamin et al. [24], accumulated clinical evidence (regarding cardiovascular health, immunity, asthma, cancer and diabetes, oxidative stress, insulin resistance, and irritation of the intestinal tract) indicates that there is no consistent result regarding the safety and efficacy of CLA. CLA is not eliciting significantly promising and consistent health effects to uphold it as either a functional or a medical food [24]. Yet, there are studies stating that the health effects of conjugated fatty acids are not yet fully demonstrated in humans. Therefore, clinical evidence appears to be insufficient regarding the effects of CLA supplements on body fat reduction as it depends on isomer type and dose $[25,26]$.

In this review, not only the possible health effects of different types of TFAs but also dietary intakes and worldwide regulatory procedures are presented and discussed.

\section{Objectives and Methods}

Despite a plethora of studies discussing the various effects of TFAs (LDL/HDL cholesterol ratio, progression of cell apoptosis, relation to immune response, cancer, etc.), there is no definite conclusion on whether nTFAs have similar adverse effects as iTFAs. Some of the adverse health effects of TFAs, such as cardiovascular disease (CVD) risk, are very well known and documented; however, there is little research showing whether the health effect of TFAs is related to its type, source, and composition [27]. Thus, there is a need to thoroughly analyze the literature and obtain an overall picture on the health influences of TFAs considering their origin and the possible transformations they undergo in organisms. It is particularly important to understand whether both nTFAs and iTFAs have similar detrimental effects on health, or whether some bacterial transformations or cattle diet manipulations can be used to improve or mitigate the adverse effects of TFAs, which are highly debated and need to be addressed.

The present article reviews the literature concerning TFAs, including metabolic studies and epidemiological investigations, with the aim of providing an overview of the different health effects of TFAs and identifying if there is a relation between TFA source and its health effects. It gives an account of recent advances in the field and draws comparisons between TFAs from industrial and ruminant origins, putting special emphasis on the latter, as it has been a central topic of debate. Moreover, the review presents and discusses the recent regulatory actions towards elimination of TFA in human diet.

To cover the literature on the topic, multiple databases were included in the research stage of the study. PubMed, Medline, Cochrane Library, Google Scholar, Scopus, and Web of Science were used to find articles relevant to the topic. During the searching process, the key words "trans fatty acid", "ruminant trans fatty acids", "industrial trans fatty acids", "conjugated linoleic acid", "conjugated linolenic acid", "conjugated fatty acids", and "vaccenic acid" were used and each was combined in the search with the keywords "microbiota", "microbiome", "LDL and HDL cholesterol", "cardiovascular disease", "cancer", "inflammation", "insulin resistance", "diabetes" "oxidative stress", "atherosclerosis", "health", "obesity", "cardiometabolic disease", "hypercholesterolemia", and "trans fatty acid regulation". In addition to the database search, the reference lists of the articles found were scanned in order not to miss any information on the health effects of different types of TFAs, as well as information on their intake. 
Afterwards, the database was filtered to exclude articles that did not include information on health effects. While analyzing the studies, special focus was given to identifying the relationship between TFAs' origin/type and its adverse/beneficial health effects. Moreover, additional literature was analyzed regarding trans fat regulation and comparisons were drawn between different geographical regions.

The information from the analyzed database for references is presented in a PRISMA diagram (Figure 2).
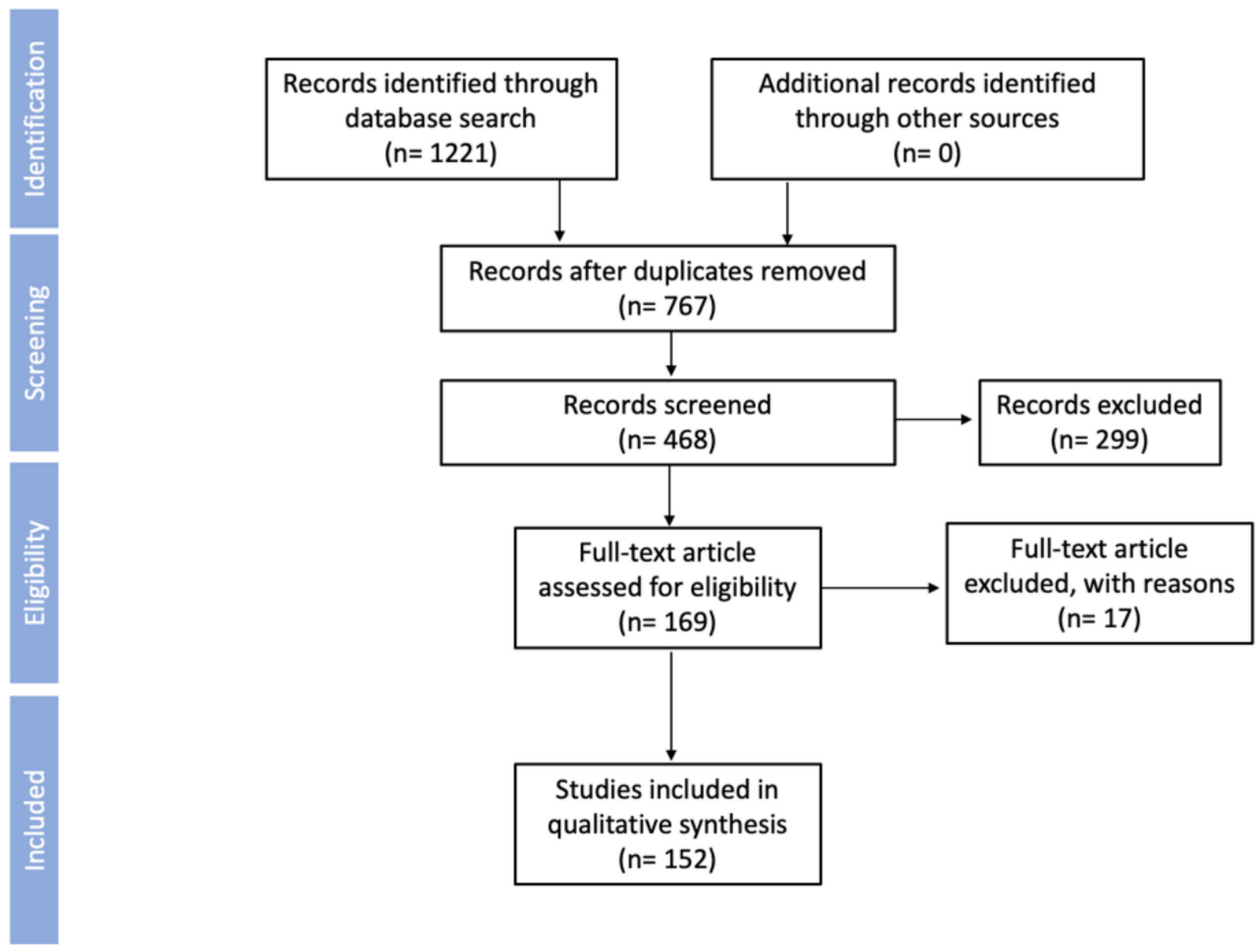

Figure 2. PRISMA flow diagram.

\section{Health Effects of TFAs}

\subsection{Obesity}

Obesity is recognized as a chronic or noncommunicable disease and an important public health problem due to its comorbidities, such as dyslipidemia, hypertension, and insulin resistance, that frequently occur in this condition. It is known that a diet with a high fat content can lead to obesity, especially in diets rich in saturated fatty acids. Contrariwise, the TFAs' effects on obesity induction is controversial and discussed below.

Effects on body fat mass (BFM) reduction by CLA were found in the literature [28-31]. In particular, Gaullier and collaborators reported that a CLA mixture $(80 \%$ trans- 10 , cis12 and cis-9, trans-11 isomers) significantly reduces BFM among healthy overweight adults [30]. Blankson and coworkers reported that $3.4 \mathrm{~g} /$ day of CLA (50:50 ratio of cis-9, trans-11 and trans-10 cis-12 isomers) given to overweight and obese humans for 12 weeks significantly reduces BFM, but not body mass index [31]. Another similar study including the same mixture of CLA isomers was conducted among overweight and grade I obese Chinese subjects. CLA (50:50 ratio of cis-9, trans- 11 and trans-10, cis- 12 isomers) supplementation of $3.4 \mathrm{~g} /$ day for 12 weeks resulted in a decrease in body weight, body mass index, body fat mass, fat percentage, subcutaneous fat mass, body fat percentage, and waistto-hip ratio. However, there was no change in lean body mass after CLA supplementation for 12 weeks [32]. Based on another study of 122 obese subjects without comorbidities, after 1 year of CLA supplementation, no significant difference in body weight or body fat regain was observed. Subjects were exposed to a $3.4 \mathrm{~g} /$ day CLA supplementation (consisting of 
$39 \%$ cis- 9 , trans- 11 isomers and $41 \%$ trans- 10 , cis- 12 isomer as triacylglycerol; the remaining $20 \%$ of the lipid content consisted of triacylglycerol). Similar health effects were also found in relation to CLA-precursor vaccenic acid, even if mostly in animal model studies. In the first study of Wang and colleagues, the 3 week $1.5 \%$ vaccenic acid supplementation in obese and insulin-resistant JCR:LA-cp rats determined the $40 \%$ decrease in fasting triglyceride concentrations [33]. A later study on the same animal model supplemented with $1 \%$ vaccenic acid for 8 weeks showed a stimulated adipose tissue redistribution, a reduced total body fat, and a decreased adipocyte size in comparison to control without vaccenic acid supplementation, thus alleviating the features of metabolic syndrome [34]. However, similar results were not found in another obesity animal model, the fa/fa Zucker rat. Indeed, although the authors found a reduced adipocyte size after a 1.5\% vaccenic acid supplementation for 8 weeks, the other obesity-related metabolic abnormalities neither worsen nor were mitigated [35]. In another double-blinded, crossover trial 27 individuals with overweight, borderline hypercholesterolemia were exposed to CLA supplementation. Participants consumed $3.5 \mathrm{~g}$ /day of sunflower oil (50:50 ratio of trans-10, cis-12, and cis-9, trans-11 isomers, Clarinol G-80, and cis-9, trans-11 isomer). The CLA intervention did not affect changes in body weight, body composition, or blood lipids [36].

Different data were found in relation to iTFAs, where a positive correlation between iTFA consumption and obesity was found. In the EPIC-PANACEA (Physical Activity, Nutrition, Alcohol, Cessation of Smoking, Eating out of Home, and Obesity) study, the doubling of elaidic acid was associated with a decreased risk of weight loss [37]. In the Spanish INMA (INfancia y Medio Ambiente) study similar results were found in 4- to 5-year-old children. Indeed, iTFA intake of $>0.7 \mathrm{~g} /$ day was positively associated with being overweight, including obesity; differently, in the same study, no significant association for nTFAs was found [38]. The same results were confirmed in the cross-sectional study of Honicky and colleagues on children and adolescents who underwent a procedure to treat congenital heart disease. In this study, the patients that exceeded the iTFA intake recommendation of $1 \%$ of energy had a 5 -fold increase of central adiposity [39]. Some recent explanations have related the iTFA consumption with the increased genetic susceptibility of the obesity-associated gene polymorphisms (rs1121980, rs1421085, and rs8050136) and BMI or weight changes, highlighting the important role that iTFAs can have on human metabolism [40].

\subsection{Insulin Resistance}

Type 2 diabetes is the most common hyperglycemic pathology caused by the condition in which the body becomes resistant to insulin. As seen in obesity, the consumption of a high fat diet and a high intake of saturated fatty acids are associated with an increased risk of type 2 diabetes. Similarly, some evidence shows that a high intake of TFAs can result in increased insulin resistance [41]. Clinical trials including healthy and overweight or diabetic individuals showed that TFAs worsen insulin resistance in overweight or diabetic individuals (those with preexisting insulin resistance) but may have smaller effects in young lean subjects. Those with preexisting insulin resistance had both higher fasting insulin and insulin resistance in the case of palm oil and partially hydrogenated soybean oil diets, compared with canola or soybean oil diets [42]. In the paper of Itcho and colleagues [43], two Japanese cohorts of Japanese Americans and native Japanese were compared in relation to serum elaidic concentration and its association with insulin resistance. The serum elaidic acid concentration was significantly higher in the Japanese Americans than in the native group. In the native Japanese, the serum elaidic acid concentration of the group with diabetes mellitus was significantly higher in comparison to normal glucose tolerance and impaired glucose tolerance groups $(16 \mu \mathrm{mol} / \mathrm{L}, 10.8 \mu \mathrm{mol} / \mathrm{L}$, and $11.7 \mu \mathrm{mol} / \mathrm{L}$, respectively) [43]. Similar positive associations were found in a US cohort of 3801 participants where total TFAs, elaidic acid, palmitelaidic acid, and vaccenic acid were significantly positively associated with fasting glucose, fasting insulin, insulin resistance index, and glycated hemoglobin $>6.5 \%$ [44]. A study including 183 individu- 
als (127 individuals without insulin resistance and 56 with insulin resistance) indicated that trans fat intake impairs insulin sensitivity affecting insulin signaling via intracellular kinases, which alters insulin receptor substrates [45]. Some studies tried to explain the molecular mechanism behind the impaired glucose tolerance induced by TFAs, and some correlations have been found with impaired insulin-dependent GLUT4 translocation [46], impaired IRS1-PI3-Akt pathway involved in GLUT4 translocation [47], and ER-stress and inhibition of insulin receptors [48]. Conflicting results were instead found for vaccenic acid. Indeed, despite a study that compared the fatty acid composition in triglycerides between normoglycemic-normoinsulinemic and hyperglycemic-hyperinsulinemic men showing vaccenic acid was positively correlated with the second group [49], many other lines of evidence suggest that vaccenic acid can have a positive impact on insulin resistance. Recently, high plasmatic levels of the CLA-precursor vaccenic acid were found to be inversely associated with insulin resistance. In particular, it was related to $17 \%, 32 \%$, and 39\% lower risks of incidence of type 2 diabetes in black, Hispanic, and Chinese American populations. Conversely, palmitoleic acid was found to be positively associated with a greater risk (21\%) of incidence of type 2 diabetes [50]. Moreover, CLA supplementation did not result in significant differences in reported adverse effects or indexes of insulin resistance; however, it has increased the number of leukocytes [51]. Another double-blind, randomized, controlled trial study was conducted including 62 healthy subjects who received either $3.9 \mathrm{~g} /$ day CLA or $3.9 \mathrm{~g}$ high oleic acid sunflower oil for 12 weeks. The CLA capsule contained $65.9 \%$ CLA (consisting of $29.7 \%$ cis-9, trans- 11 isomer and $30.9 \%$ cis- 10 , trans- 12 isomer), and minimal amounts of other CLA isomers (2.9\%). In addition, the capsule contained oleic acid (18:1n-9, 24.7\%), and a small amount of palmitic acid (16:0; 3.5\%), stearic acid $(18: 0 ; 1.3 \%)$, and linoleic acid $(18: 2 n ; 9 ; 12 ; 1.9 \%)$. CLA supplementation reduced plasma insulin concentrations in response to an oral glucose challenge in healthy women, but there were no CLA-specific effects on body composition, energy expenditure, or appetite $[52,53]$.

\subsection{Cardiovascular Disease (CVD)}

The World Health Organization (WHO) identified CVDs as the most common cause of worldwide death. CVDs included a group of disorders of the heart and blood vessels such as coronary heart disease, cerebrovascular disease, deep vein thrombosis, pulmonary embolism, peripheral arterial disease, rheumatic diseases, and congenital heart diseases. They are usually associated with atherosclerosis, caused by fatty deposits inside the arteries, and determining the hyperlipidemia as a risk factor. There are numerous studies providing evidence that iTFAs increase the risk of coronary heart disease [54]. It has been stated that TFA consumption perturbs the body's ability to metabolize essential fatty acids (including omega-3 fatty acids) leading to changes in the phospholipid fatty acid composition in the aorta, thus increasing the CVD risk [55]. Based on a study including patients with CVD, it has been proved that changes in the composition of phospholipids and fatty acids of membrane lipids largely determine the development of CVD [56]. Other studies have supported that some plasma phospholipid SFAs, such as palmitic (16:0) and stearic (18:0) acids increase the risk of coronary heart disease [57,58]. The Nurses' Health Study, which is the largest epidemiological study in this field, showed a significant, positive association between the intake of iTFAs and heart disease risk [22]. In the Framingham study, a significant, moderately increased risk of heart disease was found associated with the intake of margarine, which is a major source of TFAs [59]. Moreover, according to the Finnish Alpha-Tocopherol, Beta-Carotene Cancer Prevention Study, the increased risk of cardiac death is positively associated with the intake of total TFAs as well as elaidic acid and TFAs from hydrogenated vegetable fats [60]. In addition, Mozaffarian et al. [42] found that the consumption of iTFAs has adverse effects on plasma lipids (for example, higher LDL cholesterol, lower HDL cholesterol, and higher total/HDL cholesterol ratio), proinflammatory effects (for example, higher levels of tumor necrosis factor- $\alpha$ activity, higher interleukin-6, and higher C-reactive protein), and endothelial dysfunction. 
Harvey et al. [61] found that linoelaidic acid appeared to be potentially more detrimental than elaidic acid. Li et al. [62] showed that linoelaidic acid induces a stronger lesion effect on HUVECs compared to elaidic acid, but further studies will be necessary to identify the underlying mechanism involved in these processes. Interestingly, evidence was brought that TFAs can increase the risk of CVDs to an extent equal to or even greater than SFAs [63,64]. It is noteworthy that according to the WHO report, about 540,000 deaths yearly can be attributed to the intake of TFAs from industrial sources [65].

It should, however, be noted that the intake of TFAs from ruminant sources has either not been associated or has been negatively associated with the risk of coronary heart disease [66]. Indeed, although an early study by the US Department of Agriculture showed that vaccenic acid raises both HDL and LDL cholesterol [67] and this was further supported by the study of Øie and colleagues [68] that found high levels of vaccenic acid were associated with disease severity and mortality in 183 patients with chronic heart failure [68], subsequent studies disconfirmed this. According to the Nurses' Health Study, there is a nonsignificant, inverse association between the intake of nTFAs from ruminant sources and the risk of heart disease, indicating the association between heart disease and TFAs was due to partially hydrogenated vegetable fat rather than to isomers from ruminant sources [69]. The same pattern was observed in the Alpha-Tocopherol, Beta-Carotene Cancer Prevention Study [70]. Additionally, studies have shown that vaccenic acid can be beneficial against CVD. Indeed, Bassett and coworkers [71] found that butter enriched in vaccenic acid did not induce atherosclerotic plaque formation and reduced the serum cholesterol and triglyceride levels in LDL receptor deficient mice in comparison to regular butter [71]. Later, Kim and colleagues [72] tried to explain the mechanism behind the anti-atherogenic effect of vaccenic acid and in their in vitro study found that, unlike elaidic acid, vaccenic acid and CLA did not induce vascular smooth muscle cell proliferation and migration, steps that normally take place during atherosclerotic plaque formation [72] Furthermore, some anti-inflammatory activities were found in relation to CLA and vaccenic acid. Initially these activities were only attributed to cis-9, trans-11 CLA, which was found to modulate the transcription of TNF-alpha, IL-12, and IL-16, and the production of IL12 [73]. Finally, based on the meta-analysis of Derakhshande-Rishehri and coworkers [74], both CLA supplements and foods enriched with CLA caused a significant reduction in LDL cholesterol levels among the healthy adult population. Foods enriched in CLA, in comparison with CLA supplementation, had a beneficial effect on the whole lipid profile, although only the effect on LDL cholesterol levels was statistically significant [74].

\subsection{Cancer}

Cancer is the second leading cause of worldwide death, accounting for an estimated 9.6 million deaths. Lung, prostate, colorectal, stomach, and liver cancer are the most common types in men. Breast, colorectal, lung, cervical, and thyroid cancer are the most common in women. Cancer starts when cells grow out of control and spread throughout the body. According to Stender et al. [22], there is a positive relationship between TFA intake and the incidence of breast and large intestine cancer [22]. Similarly, more recently, Ardisson Korat and colleagues [75] found a positive relationship between TFA levels in red blood cell membrane and the risk of large B cell lymphoma, especially for elaidic and vaccenic acid [75]. In the European Prospective Investigation into Cancer and Nutrition (EPIC), Yammine et al. [76] suggested a positive association between ovarian cancer and intake of industrial trans elaidic acid. In the same EPIC study the dietary iTFAs, particularly elaidic acid, were positively associated with rectal cancer [77]. TFAs have been hypothesized to influence breast cancer risk; however, relatively few prospective studies have examined this relationship. Matta et al. [78] support the hypothesis that higher dietary intakes of iTFAs, in particular elaidic acid, are associated with elevated breast cancer risk. The effects of elaidic acid on colon carcinogenesis remain controversial; plasma concentration of elaidic acid is higher in colon adenoma patients than in healthy controls [79]. Ohmori et al. [80] showed that elaidic acid might provide metastatic potential to colorectal cancer cells. It is interesting 
that in the Netherlands Cohort Study on Diet and Cancer, a weak positive relationship between CLA intake and the incidence of breast cancer was found (for CLA, a total of cis-9, trans-11 and trans-9, cis-11 isomers were used) [81]. Moreover, according to Benjamin and coworkers [82], the negative effects of CLAs can also include colon carcinogenesis induction.

Nevertheless, in the case of uncontrolled cell proliferation, the TFAs' action is elusive in the literature data. In addition, the role of vaccenic acid is controversial, being deemed both dependent and independent from its conversion to CLA. Indeed, in vivo animal studies in rats showed that the anticarcinogenic actions of vaccenic acid against mammary carcinogenesis is dependent on its conversion to cis-9, trans-11 CLA by $\Delta 9$ desaturase [83-85]. In an early in vitro study, it was stated that vaccenic acid showed no antiproliferative effects in comparison to cis-9, trans-11 CLA that determined cell differentiation in Caco-2 cells [86]. Later studies confirmed the anticarcinogenic action of vaccenic acid independently from CLA isomers in breast carcinoma cells $[87,88]$ finding correlations with the mitochondrial-mediated apoptosis pathway [89]. Vaccenic acid inhibits proliferation and induces apoptosis of human nasopharyngeal carcinoma cells [89]. The consumption of CLA from dairy products reduces breast and colorectal cancer. A 3 year study on more than 60,000 women suggests that high intake of high fat dairy foods and CLA may reduce the risk of colorectal cancer, the third most common incident cancer worldwide [90]. Another study conducted on more than 500,000 individuals (4992 incident cases of colorectal cancer) from America and the US suggests that higher consumption of milk and calcium is inversely associated with the risk of colorectal cancer [91]. Mohammadzadeh and coworkers [92] reported that based on a randomized, double-blind study, including 34 patients with rectal cancer, who have received $3 \mathrm{~g} /$ day CLA for 6 weeks, CLA supplementation improved inflammatory factors, matrix metalloproteinase-2, and matrix metalloproteinase- 9 as biomarkers of angiogenesis and tumor invasion [92]. Several other cohort studies also suggest that increased consumption of total dairy products and CLA-rich foods reduces the risk of breast cancer $[93,94]$. However, it is important to note that the literature regarding CLA effects on cancer varies from study to study. As mentioned above, according to other studies, CLAs may lead to colon and breast cancer [81,82]. It has also been suggested that the consumption of dairy products (particularly cheese) may be a factor against the development of breast cancer, supposedly due to CLA alone or together with other ingredients. In contrast, high consumption of processed ruminant meat, reflected in an increased proportion of arachidonic acid in serum fatty acids, may increase the risk of breast cancer. It shall also be highlighted that when studying the effects of a CLA-enriched diet on cancer, it is often impossible to assess the independent effects of CLA [85]; therefore, it can be concluded that there is insufficient evidence to determine whether CLA ingestion has a significant effect on cancer [95], and its mechanisms of action should be studied more thoroughly.

\subsection{Inflammation}

In recent years, systemic chronic inflammation was linked to several diseases that determine the leading causes of worldwide death, including CVDs, cancer, diabetes mellitus, chronic kidney disease, nonalcoholic fatty liver disease, and autoimmune and neurodegenerative disorders. It has been proved that TFA consumption influences multiple risk factors, including increased systemic inflammation $[96,97]$. Studies in humans usually show a relation between iTFAs and higher levels of inflammatory markers. More precisely, based on a controlled feeding study conducted among men, consumption of TFAs, stearic acid, and LMP (the sum of lauric (L), myristic $(\mathrm{M})$, and palmitic $(\mathrm{P})$ acids) diets increased the concentrations of inflammatory markers, such as C-reactive protein (CRP), fibrinogen, and interleukin 6. Moreover, stearic acid showed to increase the risk of cardiovascular disease through an increase in fibrinogen concentrations [8]. Another study conducted among ambulatory patients with chronic heart failure showed that, in contrast to palmitoleic acid, trans isomers of oleic and linoleic acids were associated with higher inflammatory marker concentrations [28]. In a similar study including obese humans without comorbidi- 
ties, CLA (50:50 ratio of cis-9, trans-11 and trans-10, cis-12 isomers) supplementation of $6.4 \mathrm{~g} /$ day for 12 weeks increased lean body mass, as well as markers of inflammation, such as C-reactive protein and interleukin-6. However, CLA supplementation did not change body fat mass, weight, body mass index, resting energy expenditure, or respiratory quotient [98]. A different in vitro study confirmed the potential negative effect of TFAs on inflammatory parameters. Indeed, the authors showed that elaidic acid, linoelaidic acid, and vaccenic acid, but not their corresponding cis isomers, enhanced the extracellular ATP-induced apoptosis activating the ASK1-p38 pathway leading to inflammation and cell death typical of TFA-related atherosclerosis [99]. Similarly, the National Health and Nutrition Examination Survey (NHANES) conducted on 5446 participants from 1999 to 2010 and measuring plasmatic TFAs and the markers of dietary inflammation revealed that elaidic acid, linoelaidic acid, and vaccenic acid were positively associated with these markers, highlighting their role in the CVD's initiation and progression [100]. Higher consumption of TFAs is a risk factor for several inflammatory diseases including inflammatory bowel disease. Higashimura et al. [101] demonstrated that elaidate, a trans-isomer of oleate, enhanced the induction of IL1 $\beta$ in colonic mucosa of colitis model mice, and increased colonic damage and myeloperoxidase activity. A study using a mouse model of hyperlipidemia demonstrated that elaidate significantly increased ROS production and NADPH oxidase expression in the aortic vessel wall [102]. TFAs have been reported to promote vascular diseases by promoting apoptosis and inflammation of vascular endothelial cells. Hu et al. [103] investigated the effects of elaidic acid and vaccenic acid on human umbilical vein endothelial cell (HUVEC) function. The results showed that both elaidic acid and vaccenic acid reduced HUVEC viability, induced cell membrane damage, and increased membrane permeability. However, the damage by elaidic acid was significantly stronger than that by vaccenic acid. The expression of ICAM-1, VCAM-1, and IL- 6 and the PGE secretion were increased and the effect of elaidic acid was significantly higher than that of vaccenic acid [103].

Contrary to the aforementioned findings, some studies have reported that TFAs do not increase markers of inflammation [104,105]. A random study including 61 healthy adults revealed that a high intake of iTFAs and conjugated linoleic acid did not substantially affect plasma concentrations of inflammatory markers [104]. A recent randomized, crossover study in 106 healthy adults suggested that there is no effect of TFAs, regardless of the source, on inflammation and cell adhesion. Neither vaccenic acid nor iTFAs had an impact on inflammation and cell adhesion [105]. Moreover, subsequently some anti-inflammatory activities were isolated and found for vaccenic acid. Indeed, Lee and colleagues [106] found that physiological concentrations of vaccenic acid enhanced the IL-10 production and suppressed TNF-alpha in mice after LPS treatment [106]; in addition, vaccenic acid and palmitoleic acid were found to reduce TNF, VCAM-1, and SOD2 inflammatory gene expression in umbilical vein endothelial cells and human hepatocellular carcinoma cells [107]. Similarly, Da Silva and coworkers found that vaccenic acid and palmitoleic decreased inflammatory prostaglandins excretion induced by TNF-alpha in vascular endothelial cells, but simultaneously increased the F2-isoprostanes oxidative stress markers [108]. Nevertheless, still nowadays the evidence in the literature is controversial as to whether the anti-inflammatory action of vaccenic acid can be attributed to itself or to its endogenous partial conversion to cis-9, trans-11 CLA. Indeed, Jaudszus and colleagues, through the analysis of the fatty acids profile before and after vaccenic acid treatment, showed that the cis-9, trans-11 CLA amount remain unaltered, suggesting that the anti-inflammatory action of vaccenic acid was independent from cis-9, trans-11 CLA [109]. However, more recently $\mathrm{Li}$ and colleagues [110] showed that when the conversion of vaccenic acid in cis-9, trans-11 CLA was inhibited by leptin, an upregulation of inflammatory ICAM-1, VCAM-1, and IL-6 occurred; conversely without leptin the vaccenic acid bioconversion rate in cis-9, trans- 11 CLA was $23 \%$, and a remarkable down-regulation of ICAM-1, VCAM-1, and IL-6 occurred [110]. Finally, recent epidemiological work cross-sectionally associated circulating 
levels of trans vaccenic acid in humans with lower adiposity, diabetes risk, and systemic inflammation [111].

\section{Do the Health Effects of TFAs Differ Depending on Their Origin?}

Our above analysis shows that, overall, iTFAs are shown to be more deleterious than ruminant-origin TFAs; however, the latter are also considered to have some adverse health effects in certain cases.

More recent inquiry (independent of the dairy industry) has found in a 2003 Dutch meta-analysis that all TFAs, regardless of natural or artificial origin, equally raise LDL cholesterol and lower HDL cholesterol levels [22]. According to Gebauer and colleagues [105], TFA (industrial ruminants, and CLA) raises the ratio of LDL to HDL cholesterol, which in turn increases the risk of coronary heart disease. However, ruminant TFAs and CLA have less effect on the LDL to HDL cholesterol ratio than iTFAs, although further studies will be needed to decide whether this difference is real or due to chance [19]. Verneque et al. [112] reported that at levels up to $1.5-7 \%$ of energy, the effect of rTFA seemed to be more than iTFA. However, rTFA seemed to be less harmful than iTFA for HDL cholesterol, although for total cholesterol and LDL cholesterol it might be worse [112].

The US National Dairy Council has asserted that the TFAs present in animal foods are of a different type than those in partially hydrogenated oils, and do not appear to exhibit the same negative effects. CLA has various beneficial physiological effects that are associated with reduced cardiovascular heart disease [113]. These effects include changes in body composition [114] and lower insulin resistance. There are other health effects, such as anticarcinogenic, antiatherogenic, anti-obesity, and antidiabetic effects and immune system enhancement. However, the latter have been investigated mainly in different animal models, and not in humans [115]. Mazidi and colleagues [116] found a negative association between TFAs and telomere length in US adults, where shorter telomere length is associated with a broad range of age-related diseases. Nevertheless, only palmitelaidic and linoelaidic were significant and negatively associated with telomere length [116]. Finally, more recently a study was conducted to ascertain the relationship between plasma TFAs and overall cause of mortality. This study showed that the iTFA elaidic acid might be associated with mortality. Regardless, no nTFAs were inversely associated with the risk of mortality [117]. Thus, it can be concluded that the source could be important for the health influence of TFAs. While iTFAs are known for many deleterious health effects, nTFAs are shown to be less harmful and, in some cases, beneficial. However, more data are needed to draw more precise conclusions. Oteng and Kersten [27] reported that there is an ongoing debate over whether iTFAs and nTFAs exert the same effects on cardiovascular health. Evidence from both preclinical and clinical studies indicated the two types of TFAs can behave similarly or differentially, depending on the biological pathway and clinical parameters under investigation [27]. According to Verneque et al. [112], both sources of TFA can increase cardiometabolic risk parameters, especially lipid profile. However, the dose of TFA and the whole composition of the food must be considered [112].

It is important to understand how TFAs are formed and whether there is a method to reduce the health effects of deleterious TFAs and to bolster those of beneficial ones. Finally, considering the importance that the study of gut microbiota has acquired in recent years to explain biochemical pathways as the basis of the etiology of various pathologies, the TFA-gut microbiota interactions study appears to be fundamental to our understanding of the TFAs' dualism in relation to health.

\section{5. nTFAs and iTFAs' Impact on Gut Microbiota: Eubiotics or Xenobiotics?}

In an attempt to understand the dual role that TFAs have on health, the analysis of their impact on gut microbiota could be valuable. Indeed, in recent years, many diseases have been related to gut microbiota functions. Considering that diet undoubtedly influences the composition of gut microbiota, providing nutrients for both the host and the bacteria, it is increasingly important to analyze the action of each molecule introduced to foods on 
gut microbiota health. Most is known in relation to the healthy systemic effects of nTFAs, but what is their impact on human gut microbiota eubiosis? Are they something similar to xenobiotics, or do human gut microorganisms have the same ability as ruminal microbiota to convert them into linoleic acid? The first evidence that CLAs may also be formed during the metabolism of linoleic acid by human gut microbiota came from the ex vivo study of Howard and Henderson [118], where linoleic acid and alpha-linolenic acid were incubated with human fecal suspension.

Few later works investigated the effect of dietary CLAs' intake in vivo on the microbiota of humans, but mostly in animal models and with mixed results. In an early study on moderately hyperlipidemic and overweight volunteers who consumed three types of milk with different types and levels of CLAs for 56 days, only a significant decrease in Bifidobacteria numbers in all three groups was shown, indicating that the effect is more attributable to milk supplementation per se, rather than CLA content [119]. In a later paper, the change in microbiota composition was analyzed in obese mice fed with a high fat, high sucrose diet alone or supplemented with $1 \%$ of cis-9, trans-11 CLA or trans-10, cis-12 CLA. After 8 weeks of feeding, faecal alpha diversity and weight decreased in all groups. However, a trans-10, cis-12 CLA enriched diet determined the increase of Butyrivibrio, Roseburia, Lactobacillus, Actinobacteria, and a new identified strain named Ileibacterium valens of the Allobaculum genus, with a reduction in Prevotella e Clostridium genera. Conversely, cis-9, trans-11 CLA supplemented diet mice were the most enriched in Bifidobacteria [120]. Nevertheless, in the recent paper of $\mathrm{Li}$ and colleagues, the supplementation of $0.2 \%$ CLA mixture (50\% cis- 9 trans-11 CLA, and 50\% trans-10, cis-12 CLA) in C57BL/6J mice fed a high fat diet to induce obesity showed sex-dependent alteration of gut microbiota compositions. For example, Desulfovibrio, a genus that produces hydrogen sulfide, was reduced in male mice but enhanced in female mice. Moreover, the pro-inflammatory Ruminococcus and Lachnospiraceae, positively linked to type 2 diabetes, increased only in female mice. Finally, a high fat diet increased the circulating LPS in both genders; the CLA treatment decreased this level only in male mice and it aggravated these conditions in female mice [121]. In the key research of Marques and colleagues, the pros and cons of 8 weeks' trans-10, cis-12 CLA supplementation in mice were evaluated and correlated with gut microbiota composition and short-chain fatty acid production. Decreased visceral fat mass and higher concentrations of acetate, propionate, and isobutyrate, as well as shortchain fatty acids, were found and correlated with changes in microbiota composition, such as lower Firmicutes and higher Bacteroidetes proportions. However, among Bacteroidetes, a high content of Porphyromonadaceae was found and previously correlated with the induction of hepatic steatosis and altered lipid metabolism [122]. Moreover, a decreased abundance of the enteric bacteria Lachnospiraceae and Desulfovibrionaceae were found, with the former having documented positive effects against Clostridium difficile colonisation in mice [123], and lower abundance was correlated with cirrhosis [124]. Meanwhile the Desulfovibrionaceae family was associated with impaired glucose tolerance and metabolic syndrome [125]. Finally, in another important paper [126], the effects of CLA (50:50 mixture of cis-9, trans-11 CLA and trans-10, cis-12 CLA) at different concentrations in the range of 2.5-40 mg/day were analyzed in C57BL6/J mice as preventive and curative treatments against dextran sulphate sodium (DSS)-induced colitis (7 days of CLA and subsequently 7 days CLA + DSS). The results showed that CLA isomers at high concentrations (40 and $20 \mathrm{mg}$ /day) are able to alleviate colitis symptoms and to reduce DSS-induced inflammation, modulating oxidative stress enzymes and inflammatory cytokines, and increasing mucin-2, goblet cells, and tight junction proteins. Furthermore, the $40 \mathrm{mg}$ /day CLA treatment was able to rebalance the gut dysbiosis induced by DSS, reducing the Bacteroides (negatively associated with IL-10 and tight junction proteins, thus having negative effects on colitis) and increasing Bifidobacterium and Odoribacter, known as a producer of short-chain fatty acids, as butyrate, with anti-inflammatory abilities [126].

If the debate is still open for the effect of nTFAs on human microbiota, the knowledge about the relation of iTFAs and human microbiota is still in its infancy. Indeed, only 
five papers were published with conflicting results and only in animal models. In the paper of Ge and colleagues [127], soybean oil and partially hydrogenated soybean oil in low $(4.27 \%)$ and high $(23.60 \%)$ concentrations were administered in mice for 8 weeks. The authors stated that a clear dysbiosis of the gut cecum microbiota was found, with an enhancement in the harmful bacteria abundance, such as Proteobacteria, the second most abundant phylum after Firmicutes, instead of Bacteroidetes as in the control group, and Desulfovibrionaceae [127]. This last taxon is known to increase the permeability of the gut mucus membrane due to excessive $\mathrm{H}_{2} \mathrm{~S}$ production, and therefore increases inflammation of the colonic epithelium [128], correlated in the present paper with high expression of inflammatory cytokines [127]. In support of the iTFA-induced dysbiosis, in the same study, a relative abundance decrease in beneficial bacteria was recorded for Bacteroidetes, Lachospiraceae, Rikenellaceae, and Bacteroidales S24-7. A decreasing abundance of the beneficial Lachospiraceae was also found after administration of nTFAs discussed above [122], and, thus, it is likely that TFAs in general act as toxic elements for this bacteria taxon. Reduced abundance of Rikenellaceae was previously correlated with nonalcoholic fatty liver disease [129], and in this study impaired liver functions were found and probably relate to this taxon dysbiosis [126]. Beyond expectations, iTFA supplementation also enhances the relative abundance of Lactobacillaceae, considered beneficial bacteria, enough to also be used as a probiotic [127]. However, the increase of Lactobacillaceae cannot be correlated with a healthy status considering that in previous studies its increase was related to impaired conditions in mice, for example, obesity and steatohepatitis [130]. Similarly, the same authors in their recent paper confirm this dysbiotic effect of iTFAs' supplementation in the small intestine of C57BL6/J mice. Indeed, after 8 weeks of feeding with soybean oil and partially hydrogenated soybean oil in low ( $10 \% \mathrm{kcal}$ from fat) and high ( $45 \% \mathrm{kcal}$ from fat) concentrations, Proteobacteria, Lactobacillus, and Desulfovibrio were found to be significantly higher in the iTFA groups in comparison to non-iTFA groups [131]. Conversely to what was shown above, in the study of Carvahlo and coworkers [132], the authors stated that high fat and iTFAs, in the form of partially hydrogenated vegetable oils, are less harmful than expected [132]. The research contemplated a 13 week13-week experimental period in which four different high fat diets were administered to mice, and in which the alternation of partially hydrogenated fats and whey protein hydrolysates (with demonstrated anti-inflammatory properties) were combined and compared with a control diet. In the discussed results, the authors stated that, even though Bacteroidetes decreases and Firmicutes increases, the general predominance of Bacteroidetes was maintained. Conversely to the previously described studies, here the Proteobacteria abundance was higher in an unhydrogenated oil diet (composed at $93 \%$ of soybean oil), particularly when not associated with whey protein hydrolysates. Thus, the iTFA diet seemed to be more conservative for the original microbiota population in comparison to the unhydrogenated high fat diet. However, some changes were recorded, in particular an increase in Parabacteroides goldsteinii and Akkermansia muciniphila in an iTFA-containing diet, whereas Butyricimonas, Actinocorallia, and Natronincola decrease [132]. Parabacteroides goldsteinii is a pathogenic species associated with bacteraemia in humans [133] and it increased in this study after iTFA supplementation. On the contrary, Butyricimonas synergistica and B. virosa decrease and were associated with bacteraemia in humans [134], while Akkermansia muciniphila increased and was correlated with the improvement of several metabolic parameters [135]. From this mixed result, the authors stated that iTFA supplementation mostly does not determine the dysbiosis of gut microbiota in mice [132]. Nevertheless, two recent papers further support the dysbiotic effect of the iTFAs. In the paper of Hua and coworkers [136], Sprague Dawley rats fed $1 \%$ and $8 \%$ of partially hydrogenated soybean oil in a high fat diet showed the same altered parameters as the animals fed a high fat diet with a high level of lard. Indeed, the diets significantly induced obesity and changes in the microbiota composition as shown by the inversely altered Firmicutes and Bacteroidetes ratio, the increase in Proteobacteria and Bacteroides, and the decrease in Muribaculaceae, that may affect inflammation [136]. Similarly, in the paper of Okamura and colleagues [137], C57BL6/J mice fed a high trans, high 
sucrose diet, in addition to an increase of elaidic acid in the liver and serum together with increased blood glucose levels and intestinal inflammation, showed a significantly higher abundance of the family Desulfovibionaceae, belonging to the phylum Proteobacteria [137].

In conclusion, TFAs' influence on gut microbiota seems to follow the same trend previously seen for other health conditions: nTFAs are more beneficial for health in comparison to iTFAs, which are more similar to xenobiotics. However, considering the mixed results obtained on both fronts, and the shortage of human investigations, further and deeper analyses are needed to outline the real TFA effects on human gut microbiota.

\section{Comparison of the Regulations and Reduction Policies of TFAs Worldwide}

As it has been noted above, iTFA intake has a negative impact on the heart. Hence why, in recent years, different health organizations have recommended the lowering of iTFA intake as much as possible [138].

According to the European CVD statistics, trans fat consumption significantly increases the risk of CVD, which is the main cause of death for Europeans under the age of 65 [139]. The WHO reports that a $2 \%$ increase in energy from trans fats leads to a $25 \%$ increase in the risk of death from CVD [140].

According to the National Academy of Sciences of the USA, dietary TFAs are more deleterious for coronary artery disease than saturated fatty acids [138]. Interestingly, EFSA stated that even though the effect of TFAs on heart health may be greater than that of saturated fats, given the current intake levels of TFAs, their potential to increase cardiovascular risk is much lower than that of saturated fats [141]. A comprehensive report was published by the National Academy of Science, Institute of Medicine in July 2002, recommending that the intake of TFAs should be as low as possible, without differentiating between iTFAs and TFAs from ruminants [142]. The World Health Organization recommended in 2003 that all trans fats be limited to less than 1\% of overall energy intake. EFSA Opinion 2004 [2] suggested that, from 2 April 2021 onwards, foods in the EU intended for consumers must contain less than $2 \mathrm{~g}$ of iTFAs per $100 \mathrm{~g}$ of fat. The first European country that has imposed a limit on iTFAs in food is Denmark. The limitation to $2 \mathrm{~g}$ per $100 \mathrm{~g}$ of fat has been quite successful as CVD mortality has decreased significantly in 3 years.

According to the scientific opinion published by EFSA in 2018 [141], the majority of European countries still do not limit the content of trans fats in food. It should be mentioned that the policy option on the TFA ban includes the legislation limiting only the amount of iTFA, but doesn't apply to TFAs from natural sources (i.e., nTFA). Moreover, the European Commission proposed a legal limit on iTFAs in food according to which, "The content of trans fat, other than trans-fat naturally occurring in animal fat, in foods which is intended for the final consumer, shall not exceed $2 \mathrm{~g}$ per $100 \mathrm{~g}$ of fat." This provision came into force in April 2021. The European Margarine Association (IMACE) welcomed the adopted legislation by the European Commission setting a legal limit on the content of iTFAs in food sold in retail and intended for the final consumer.

In 2020, the Pan American Health Organization (PAHO) published the 2020-2025 plan of action for the elimination of iTFAs [143]. Two main policies are mentioned as effective approaches to eliminate iTFAs. The first approach uses legislative or regulatory measures to limit iTFA to no more than $2 \mathrm{~g}$ per $100 \mathrm{~g}(2 \%)$ of total fat in all food products, including, but not limited to, fats and oils. Similar to EU practice, the PAHO's first approach applies to domestic and imported products but excludes TFAs from ruminant sources. The second and more recent policy approach is to ban partially hydrogenated oils (PHO), the major source of dietary iTFA. It is worth mentioning that the US has reclassified PHO as no longer "generally recognized as safe". Moreover, Canada has listed PHOs among "contaminants and other adulterating substances in food". Peru and Thailand have adopted measures that are similar to those of Canada and the US [143,144].

The legal limit on trans fats in the Eurasian Economic Union seem to be less stringent. The Customs Union has set "Technical regulations for fat-and-oil products" (TR TS 024/2011) [145], which came into force in Russia in 2018. According to the regulation, 
the safety parameter for "trans-isomers of fatty acids" has changed from $20 \%$ to $2 \%$ of the product's total fat content. Following the new regulation, foods that contain trans fats, such as margarine, special fats, cream vegetable and vegetable fat spreads, cream vegetable and vegetable fat rendered mixtures, milk fat substitutes, cacao butter, and cacao butter equivalents must contain up to $2 \%$ of trans-isomers. Moreover, it is mandatory to indicate the ratio of the product's fat content on the package. The requirements regarding the content of trans-isomers of fatty acids had been changing since 2013 and the process finished on 1 January 2018. This long period gave fat and oil producers time to adapt to the new requirements, which are now effective in all Eurasian Economic Union (EAEU) countries.

It is important to note that the methodology of food control systems incorporates not only the needs of the country, but also cultural aspects and technical infrastructures. The approaches to food safety control in the EAEU and EU are fundamentally different. The EAEU approach is based on the testing of final products in compliance with specific technical regulations or standards. These differences consequently have an impact on the food safety control system as a whole, including the organization of monitoring and control, inspection, testing, labeling, approaches to food quality, and the responsibilities of government, industry, and consumers. The word "risk" in the legislation of the Eurasian Economic Union is not specific to food products. Risk assessment is defined as the key tool of sanitary epidemiological activities. It should be highlighted that in some cases these notions are raising the profile of the concept of internationally adopted approaches; for example, Appendix 9, "Protocol on Technical Regulation within the Eurasian Economic Union", the Agreement of the Eurasian Economic Union, defines risk as a combination of the probability of harm and the consequences of this harm impacting human life and health (in terms of the sanitary and epidemiological wellbeing of the residents). Therefore, the approach adopted by the EAEU is hazard-based. In comparison, the EU-adopted modern approach is a risk-based food safety control system. The peculiarity of this approach is that the food business operators are responsible for food safety hazard identification, its consequent risk, and the implementation of practices for prevention, minimization, and elimination of hazards. The government is responsible for monitoring and verifying the effectiveness of the risk control measure. In Regulation (EU) No 1169/2011 [146] trans fats are defined as "fatty acids with at least one non-conjugated (namely, interrupted by at least one methylene group) carbon-carbon double bond in the trans configuration". Meanwhile, the Union Technical Regulation for Fat and Oil Products [145] omits the definition of TFAs in its "Terms and Definition" chapter. On 24 April 2019, the Commission adopted a Commission Regulation Amending Annex III to Regulation (EC) No 1925/2006 of the European Parliament and of the Council [147] regarding trans fats, other than trans fats naturally occurring in fat of animal origin. The maximum limit of trans fats in food intended for the final consumer and for supply to retail is $2 \mathrm{~g}$ per $100 \mathrm{~g}$ of fat. The novelty of legal changes is an obligation for business-to-business transmission of information on the amount of trans fats in foods when it exceeds the limit of $2 \%$ of fat. It is noteworthy that in 2018, several standards for the permissible level of fatty acid trans isomers established by the EAEU Technical Regulation for Fat and Oil Products [145] came into force after the transitional period had elapsed. The content of trans fats in solid, soft, and liquid margarines, milk fat substitutes, and special purpose fats should not exceed $2 \%$ of the total fat content in food products (as opposed to the $8-20 \%$ safety limit previously). Nevertheless, there is no labeling requirement for products other than fats and oils in the EAEU, which is also a fundamental difference compared to the EU.

The WHO has developed the TFA Country Score Card (Table 1) which shows countries that have best practice TFA policies, less restrictive TFA limits, other complementary measures, or a national policy commitment to eliminate TFA [144]. 
Table 1. TFA Country Score Card developed by the WHO [144].

\begin{tabular}{ll}
\hline \multicolumn{1}{c}{ Score } & \multicolumn{1}{c}{ Countries } \\
\hline & Nof Countries \\
& Barbuda, Bahamas, Bangladesh, Barbados, Belize, \\
& Benin, Bhutan, Bosnia and Herzegovina, Botswana, \\
& Cambodia, Chad, Costa Rica, Côte d'Ivoire, \\
& Djibouti, Dominican Republic, Egypt, Eswatini, \\
& French Polynesia, Ghana, Grenada, Guatemala, \\
& Guyana, Indonesia, Jamaica, Kenya, Lao People's \\
1. National policy commitment to eliminate TFA: & Democratic Republic, Lebanon, Maldives, \\
National policies, strategies, or action plans that & Mauritania, Mauritius, Mongolia, Morocco, \\
express a commitment to reduce iTFA in the food & Myanmar, Namibia, Nauru, Nepal, Nigeria, North \\
supply & Macedonia, Papua New Guinea, Qatar, Saint Kitts \\
& and Nevis, Saint Lucia, Saint Vincent and the \\
& Grenadines, Samoa, Seychelles, Sri Lanka, \\
& Suriname, Timor-Leste, Trinidad and Tobago, \\
& Turkmenistan, Ukraine, United Arab Emirates, \\
& Vanuatu, Venezuela (Bolivarian Republic of), West \\
& Bank and Gaza Strip, Zambia \\
\hline
\end{tabular}

2. Other complementary measures: Legislative or other measures that encourage consumers to make healthier choices about iTFA or mandatory limits on iTFA in foods in specific settings

3. Less restrictive TFA limits: Legislative or regulatory measures that limit iTFA in foods in all settings, but are less restrictive than the recommended approach
Best practice TFA policy passed but not yet in effect

Monitoring mechanism for mandatory TFA limits
Bolivia (Plurinational State of), Brazil, Brunei

Darussalam, Cape Verde, China, El Salvador,

Ethiopia, Fiji, Israel, Jordan, Mexico, Oman,

Pakistan, Paraguay, Philippines, Republic of Korea,

Republic of Moldova, Tajikistan, Tunisia

Argentina, Armenia, Bahrain, Belarus, Colombia,

Ecuador, Georgia, India, Iran, Kazakhstan, Kuwait,

Kyrgyzstan, Peru, Russian Federation, Singapore, Switzerland, Uruguay, Uzbekistan

Austria, Belgium, Bulgaria, Canada, Chile, Croatia, Cyprus, Czechia, Denmark, Estonia, Finland,

France, Germany, Greece, Guam, Hungary, Iceland, Ireland, Italy, Latvia, Liechtenstein, Lithuania, Luxembourg, Malta, Netherlands, Northern

Mariana Islands, Norway, Poland, Portugal,

Romania, Saudi Arabia, Slovakia, Slovenia, South

Africa, Spain, Sweden, Thailand, United Kingdom

of Great Britain and Northern Ireland, US

Brazil, India, Paraguay, Peru, Singapore, Uruguay
Argentina, Armenia, Austria, Belarus, Canada, Chile, Colombia, Denmark, Ecuador, Georgia, Hungary, Iceland, India, Kazakhstan, Kyrgyzstan,

Latvia, Lithuania, Norway, Peru, Russian

Federation, Saudi Arabia, Singapore, South Africa,

Switzerland, Thailand, US, Uruguay

\section{Comparison of the Intake and Health Effects of TFAs}

It is important to mention that all food products showed iTFA decline except for certain foods such as cookies, biscuits, bakery products, cake mixes, shortenings, and frozen foods that still contain high amounts of TFAs [7]. Taking into consideration the public health concerns due to TFA contents in processed foods, the global agroindustry applied changes in their manufacturing processes. Overall, different strategies, including new processes, treatments, and reformulations such as the modification of the hydrogenation process, interesterification, fractionation, or the combination of several technologies for TFA reduction, have been implemented [148,149]. Interestingly, the processed food industry has an important role in decreasing the TFA content in food by using alternative sources of 
fat with zero TFA levels. For example, the replacement of frying fats with medium and high stability vegetable oils in the fast food industry resulted in the elimination of TFAs in products fried in the fats [17].

Li et al. [13] stated that it is urgent to measure and monitor TFA intake globally. However, researchers mention that accurate and reliable data on TFA intake are scare, especially in many low and middle income countries. More recent data from different countries (Figure 3) indicate that average daily TFA intakes are below $1 \%$ of daily energy (except in the case of Iran, Lebanon, Canada, Puerto Rico, Brazil, and the US); thus, TFA intake has decreased in general $[10,148,149]$. It should be noted that some population groups are at risk of exceeding the levels recommended by the World Health Organization, $1 \%$ of the energy intake $[65,150]$.

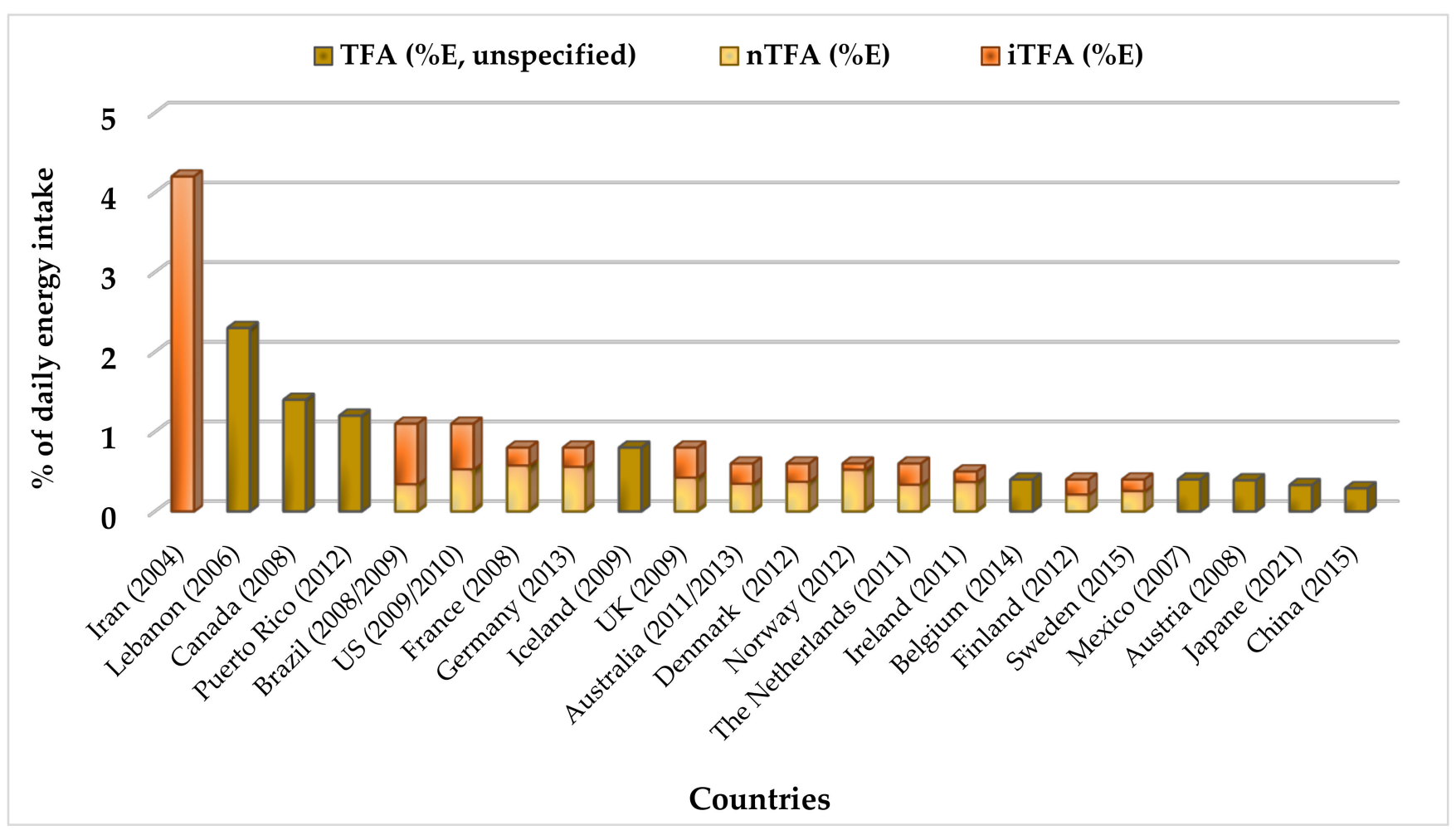

Figure 3. Mean intake of TFA as \% of daily energy intake in different countries. The red line shows the maximum intake recommended by the WHO.

In EAEU member countries, exceedingly high contents of TFAs were reported in various foods. A recent study indicates that some of the dishes surveyed in Kyrgyzstan contained up to $170 \%$ of the recommended maximum daily intake of trans fats in one serving [139]. Another study, analyzing the TFA content in commonly available products in Kyrgyzstan, found that $54 \%$ of foods showed a content of trans fats $\geq 1 \%$ [151]. Unfortunately, there is no sufficient data regarding the TFA intake levels among the population of EAEU countries. Nevertheless, as previously mentioned, the high intake of iTFAs is associated with an increased risk of coronary heart disease [152]; thus, CHD deaths due to TFA intakes are a raw estimate of TFAs' burden. To compare TFAs' burden in the EU and the EAEU, data on coronary heart disease death (\%) due to TFA intakes for both EU and EAEU countries are presented in the table below (Table 2), based on the calculation from Wang et al.'s study [29]. Overall, this measure is highly variable from country to country; however, the EU average exceeds the EAEU average. Thus, even though EU member countries have more stringent TFA limits than EAEU member countries, the proportion of CHD deaths due to TFAs, on average, is higher for EU countries. 
Table 2. Proportion of coronary heart disease death (\%) due to TFA intake $(>0.5 \%$ energy).

\begin{tabular}{|c|c|c|c|c|c|}
\hline \multicolumn{4}{|c|}{$\overline{E U}$} & \multicolumn{2}{|r|}{ EAEU } \\
\hline Country & $\begin{array}{l}\text { Proportion of CHD Death } \\
\text { (\%) Due to TFA Intake }\end{array}$ & Country & $\begin{array}{l}\text { Proportion of CHD Death } \\
\text { (\%) Due to TFA Intake } \\
\text { (>0.5\% Energy) }\end{array}$ & Country & $\begin{array}{l}\text { Proportion of CHD Death } \\
\text { (\%) Due to TFA Intake } \\
\text { (>0.5\% Energy) }\end{array}$ \\
\hline Netherlands & 14.4 & Denmark & 4.4 & Belarus & 5.8 \\
\hline Slovenia & 7 & Estonia & 4.3 & $\begin{array}{c}\text { Kazakhstan } \\
\text { Russian }\end{array}$ & 4.4 \\
\hline Austria & 6.6 & France & 4.1 & $\begin{array}{l}\text { Federa- } \\
\text { tion }\end{array}$ & 4.3 \\
\hline Latvia & 6.2 & Croatia & 4.1 & Armenia & 4.1 \\
\hline $\begin{array}{c}\text { Czech } \\
\text { Republic }\end{array}$ & 5.9 & Bulgaria & 4 & Kyrgyzstan & 3.3 \\
\hline Germany & 5.6 & Belgium & 4 & & \\
\hline Poland & 5.6 & Ireland & 3.9 & & \\
\hline Lithuania & 5.5 & Romania & 3.7 & & \\
\hline Hungary & 5.2 & Malta & 3.3 & & \\
\hline Slovakia & 5 & Italy & 3 & & \\
\hline Luxembourg & 4.8 & Sweden & 2.3 & & \\
\hline Spain & 4.7 & Finland & 2.7 & & \\
\hline Portugal & 4.6 & Cyprus & 1 & & \\
\hline Greece & 4.6 & & & & \\
\hline \multicolumn{4}{|c|}{ Average } & \multicolumn{2}{|r|}{ Average } \\
\hline \multicolumn{4}{|c|}{6.12} & \multicolumn{2}{|r|}{4.38} \\
\hline
\end{tabular}

By drawing the comparison between the aforementioned worldwide policies and legislations, as well as data on the intake of TFAs, it is crucial to highlight that, overall, regulations do not apply to the naturally occurring content of TFAs (nTFAs). Moreover, another important concern is the absence of specific data on nTFAs' consumption across these countries and regions.

\section{Conclusions}

To conclude, many studies report a direct association of iTFA intake with the risk of coronary artery disease (CAD) and other adverse health effects. Meanwhile, in regard to ruminant TFAs, studies report both a positive, negative, and sometimes no association of ruminant TFA intake with adverse health effects. Thus, TFAs from industrial sources are proved to have many adverse health effects; so why do so many companies still use it? It is because trans fats are easy to use, inexpensive to produce, and last a long time. Trans fats give foods a desirable taste and texture. Many restaurants and fast food outlets use trans fats to deep fry foods because oils with trans fats can be used many times in commercial fryers. Several countries (e.g., Denmark, Switzerland, and Canada) and jurisdictions (e.g., California, New York City, Baltimore, and Montgomery County, MD) have reduced or restricted the use of trans fats in food service establishments. Even though some adverse health effects of ruminant origin TFAs, such as CLAs, have also been reported, the negative effects of nTFAs do not transcend those of iTFAs. Therefore, it is recommended that iTFAs be used as little as possible, while the use of the ruminant depends on its type and the organism of the user. Overall, the dietary recommendations should be focused on restriction of TFA intake rather than potential health effects induced by the different types of TFAs. 
Author Contributions: Conceptualization, D.P. and N.M.; methodology, N.M.; data curation, M.B., S.S. (Stella Stepanyan), L.C., and R.M.; writing-original draft preparation, S.S. (Seda Stepanyan), S.S. (Stella Stepanyan), L.C., and R.M.; writing-review and editing, M.B. and S.S. (Seda Stepanyan); supervision, N.M.; project administration, D.P. and N.M.; funding acquisition, D.P. and N.M. All authors have read and agreed to the published version of the manuscript.

Funding: This research was funded by the Science Committee of RA, grant number "19YR-4A037".

Acknowledgments: The work was supported by the Science Committee of RA, in the frame of the research project № 19YR-4A037.

Conflicts of Interest: The authors declare that there are no conflict of interest. The funders had no role in the design of the study; in the collection, analyses, or interpretation of the data; in the writing of the manuscript; or in the decision to publish the results.

\section{References}

1. Semma, M. Trans Fatty Acids: Properties, Benefits and Risks. J. Health Sci. 2002, 48, 7-13. [CrossRef]

2. European Food Safety Autority (EFSA). Opinion of the Scientific Panel on Dietetic products, nutrition and allergies [NDA] related to the presence of trans fatty acids in foods and the effect on human health of the consumption of trans fatty acids. EFSA J. 2004, 2, 1-49. [CrossRef]

3. Allott, E.H.; Arab, L.; Su, L.J.; Farnan, L.; Fontham, E.T.H.; Mohler, J.L.; Bensen, J.T.; Steck, S.E. Saturated fat intake and prostate cancer aggressiveness: Results from the population-based North Carolina-Louisiana Prostate Cancer Project. Prostate Cancer Prostatic Dis. 2017, 20, 48-54. [CrossRef] [PubMed]

4. $\quad$ Briggs, M.; Petersen, K.; Kris-Etherton, P. Saturated Fatty Acids and Cardiovascular Disease: Replacements for Saturated Fat to Reduce Cardiovascular Risk. Healthcare 2017, 5, 29. [CrossRef]

5. Nettleton, J.A.; Brouwer, I.A.; Geleijnse, J.M.; Hornstra, G. Saturated Fat Consumption and Risk of Coronary Heart Disease and Ischemic Stroke: A Science Update. Ann. Nutr. Metab. 2017, 70, 26-33. [CrossRef]

6. Parks, E.; Yki-Järvinen, H.; Hawkins, M. Out of the frying pan: Dietary saturated fat influences nonalcoholic fatty liver disease. J. Clin. Investig. 2017, 127, 454-456. [CrossRef]

7. Aldai, N.; de Renobales, M.; Barron, L.J.R.; Kramer, J.K.G. What are the trans fatty acids issues in foods after discontinuation of industrially produced trans fats? Ruminant products, vegetable oils, and synthetic supplements. Eur. J. Lipid Sci. Technol. 2013, 115, 1378-1401. [CrossRef]

8. Valenzuela, C.A.; Baker, E.J.; Miles, E.A.; Calder, P.C. Eighteen-carbon trans fatty acids and inflammation in the context of atherosclerosis. Prog. Lipid Res. 2019, 76. [CrossRef]

9. Kim, E.J.; Huws, S.A.; Lee, M.R.F.; Scollan, N.D. Dietary transformation of lipid in the rumen microbial ecosystem. Asian-Australas. J. Anim. Sci. 2009, 22, 1341-1350. [CrossRef]

10. Wanders, A.J.; Zock, P.L.; Brouwer, I.A. Trans fat intake and its dietary sources in general populations worldwide: A systematic review. Nutrients 2017, 9, 840. [CrossRef] [PubMed]

11. Puligundla, P.; Variyar, P.S.; Ko, S.; Obulam, V.S.R. Emerging trends in modification of dietary oils and fats, and health implications-A review. Sains Malays. 2012, 41, 871-877.

12. Vargas-bello-pérez, E.; Garnsworthy, P.C. Trans Fatty Acids And Their Role In The Milk Of Dairy Cows. Cien. Inv. Agr. 2013, 40, 449-473. [CrossRef]

13. Li, C.; Cobb, L.K.; Vesper, H.W.; Asma, S. Global surveillance of trans-fatty acids. Prev. Chronic Dis. 2019, 16, 1-5. [CrossRef]

14. Huang, L.; Federico, E.; Jones, A.; Wu, J.H.Y. Presence of trans fatty acids containing ingredients in pre-packaged foods in Australia in 2018. Aust. N. Z. J. Public Health 2020, 44, 419-420. [CrossRef] [PubMed]

15. Dominguez Rodríguez, L.; Barbagallo, M. Not all fats are unhealthy. In The Prevention of Cardiovascular Disease through the Mediterranean Diet; Sánchez-Villegas, A., Sánchez-Tainta, A., Eds.; Elsevier: London, UK, 2018; pp. 35-58.

16. Chen, Y.; Yang, Y.; Nie, S.; Yang, X.; Wang, Y.; Yang, M.; Li, C.; Xie, M. The analysis of trans fatty acid profiles in deep frying palm oil and chicken fillets with an improved gas chromatography method. Food Control 2014, 44, 191-197. [CrossRef]

17. Dhaka, V.; Gulia, N.; Ahlawat, K.S.; Khatkar, B.S. Trans fats-sources, health risks and alternative approach-A review. J. Food Sci. Technol. 2011, 48, 534-541. [CrossRef] [PubMed]

18. Loor, J.J.; Lin, X.; Herbein, J.H. Effects of dietary cis 9, trans 11-18: 2, trans 10, cis 12-18: 2, or vaccenic acid (trans 11-18: 1) during lactation on body composition, tissue fatty acid profiles, and litter growth in mice. Br. J. Nutr. 2003, 90, 1039-1048. [CrossRef] [PubMed]

19. Brouwer, I.A.; Wanders, A.J.; Katan, M.B. Effect of animal and industrial Trans fatty acids on HDL and LDL cholesterol levels in humans-A quantitative review. PLoS ONE 2010, 5, e9434. [CrossRef]

20. Qiu, B.; Wang, Q.; Liu, W.; Xu, T.C.; Liu, L.N.; Zong, A.Z.; Jia, M.; Li, J.; Du, F.L. Biological effects of trans fatty acids and their possible roles in the lipid rafts in apoptosis regulation. Cell Biol. Int. 2018, 42, 904-912. [CrossRef]

21. World Health Organisation (WHO). International Agency for Research on Cancer (IARC). The Global Burden of Cancer. In World Cancer Report; IARC Press: Lion, France, 2003; Volume 22. 
22. Stender, S.; Dyerberg, J. Influence of trans fatty acids on health. Ann. Nutr. Metab. 2004, 48, 61-66. [CrossRef]

23. Fuke, G.; Nornberg, J.L. Systematic evaluation on the effectiveness of conjugated linoleic acid in human health. Crit. Rev. Food Sci. Nutr. 2017, 51, 1-31. [CrossRef] [PubMed]

24. Benjamin, S.; Prakasan, P.; Sreedharan, S.; Wright, A.G.; Spener, F. Pros and cons of CLA consumption an insight. Nutr. Metab. 2015, 12, 20. [CrossRef] [PubMed]

25. Ferlay, A.; Bernard, L.; Meynadier, A.; Malpuech-Brugère, C. Production of trans and conjugated fatty acids in dairy ruminants and their putative effects on human health: A review. Biochimie 2017, 141, 107-120. [CrossRef]

26. Lehnen, T.E.; da Silva, M.R.; Camacho, A.; Marcadenti, A.; Lehnen, A.M. A review on effects of conjugated linoleic fatty acid (CLA) upon body composition and energetic metabolism. J. Int. Soc. Sports Nutr. 2015, 12, 1-11. [CrossRef] [PubMed]

27. Oteng, A.B.; Kersten, S. Mechanisms of Action of trans Fatty Acids. Adv. Nutr. 2020, 11, 697-708. [CrossRef]

28. Mozaffarian, D.; Rimm, E.B.; King, I.B.; Lawler, R.L.; McDonald, G.B.; Levy, W.C. Trans fatty acids and systemic inflammation in heart failure. Am. J. Clin. Nutr. 2004, 80, 1521-1525. [CrossRef]

29. Wang, Q.; Afshin, A.; Yakoob, M.Y.; Singh, G.M.; Rehm, C.D.; Khatibzadeh, S.; Micha, R.; Shi, P.; Mozaffarian, D.; Ezzati, M.; et al. Impact of nonoptimal intakes of saturated, polyunsaturated, and trans fat on global burdens of coronary heart disease. J. Am. Heart Assoc. 2016, 5, e002891. [CrossRef]

30. Gaullier, J.M.; Halse, J.; Høye, K.; Kristiansen, K.; Fagertun, H.; Vik, H.; Gudmundsen, O. Conjugated linoleic acid supplementation for $1 \mathrm{y}$ reduces body fat mass in healthy overweight humans. Am. J. Clin. Nutr. 2004, 79, 1118-1125. [CrossRef]

31. Blankson, H.; Stakkestad, J.A.; Fagertun, H.; Thom, E.; Wadstein, J.; Gudmundsen, O. Conjugated linoleic acid reduces body fat mass in overweight and obese humans. J. Nutr. 2000, 130, 2943-2948. [CrossRef]

32. Chen, S.C.; Lin, Y.H.; Huang, H.P.; Hsu, W.L.; Houng, J.Y.; Huang, C.K. Effect of conjugated linoleic acid supplementation on weight loss and body fat composition in a Chinese population. Nutrition 2012, 28, 559-565. [CrossRef]

33. Wang, Y.; Lu, J.; Ruth, M.R.; Goruk, S.D.; Reaney, M.J.; Glimm, D.R.; Vine, D.F.; Field, C.J.; Proctor, S.D. Trans-11 vaccenic acid dietary supplementation induces hypolipidemic effects in JCR:LA-cp rats. J. Nutr. 2008, 138, 2117-2122. [CrossRef]

34. Jacome-Sosa, M.M.; Borthwick, F.; Mangat, R.; Uwiera, R.; Reaney, M.J.; Shen, J.; Quiroga, A.D.; Jacobs, R.L.; Lehner, R.; Proctor, S.D. Diets enriched in trans-11 vaccenic acid alleviate ectopic lipid accumulation in a rat model of NAFLD and metabolic syndrome. J. Nutr. Biochem. 2014, 25, 692-701. [CrossRef]

35. Mohankumar, S.K.; Hanke, D.; Siemens, L.; Cattini, A.; Enns, J.; Shen, J.; Reaney, M.; Zahradka, P.; Taylor, C.G. Dietary supplementation of trans-11-vaccenic acid reduces adipocyte size but neither aggravates nor attenuates obesity-mediated metabolic abnormalities in fa/fa Zucker rats. Br. J. Nutr. 2013, 109, 1628-1636. [CrossRef] [PubMed]

36. Joseph, S.V.; Jacques, H.; Plourde, M.; Mitchell, P.L.; McLeod, R.S.; Jones, P.J.H. Conjugated linoleic acid supplementation for 8 weeks does not affect body composition, lipid profile, or safety biomarkers in overweight, hyperlipidemic men. J. Nutr. 2011, 141, 1286-1291. [CrossRef] [PubMed]

37. Chajès, V.; Biessy, C.; Ferrari, P.; Romieu, I.; Freisling, H.; Huybrechts, I.; Scalbert, A.; Bueno de Mesquita, B.; Romaguera, D.; Gunter, M.J.; et al. Plasma Elaidic Acid Level as Biomarker of Industrial Trans Fatty Acids and Risk of Weight Change: Report from the EPIC Study. PLoS ONE 2015, 10, e0118206. [CrossRef] [PubMed]

38. Scholz, A.; Navarrete-Muñoz, E.M.; García-de-la-Hera, M.; Fernandez-Somoano, A.; Tardon, A.; Santa-Marina, L.; Pereda-Pereda, E.; Romaguera, D.; Guxens, M.; Beneito, A.; et al. Association between Trans Fatty Acid Intake and Overweight Including Obesity in 4 to 5-year-old Children from the INMA Study. Pediatr. Obes. 2019, 14, e12528. [CrossRef] [PubMed]

39. Honicky, M.; Cardoso, S.M.; Lima, L.R.A.; Ozcariz, S.G.I.; Vieira, F.G.K.; Carlos Back, I.; Moreno, Y.M.F. Added Sugar and Trans Fatty Acid Intake and Sedentary Behavior Were Associated with Excess Total-body and Central Adiposity in Children and Adolescents with Congenital Heart Disease. Pediatr. Obes. 2020, 15, e12623. [CrossRef]

40. Koochakpour, G.; Esfandiar, Z.; Hosseini-Esfahani, F.; Mirmiran, P.; Daneshpour, M.S.; Sedaghati-Khayat, B.; Azizi, F. Evaluating the Interaction of Common FTO Genetic Variants, Added Sugar, and Trans-Fatty Acid Intakes in Altering Obesity Phenotypes. Nutr. Metab. Cardiovasc. Dis. 2019, 29, 474-480. [CrossRef]

41. Risérus, U. Trans fatty acids, insulin sensitivity and type 2 diabetes. Scand. J. Food Nutr. 2006, 50, 161-165. [CrossRef]

42. Mozaffarian, D.; Aro, A.; Willett, W.C. Health effects of trans-fatty acids: Experimental and observational evidence. Eur. J. Clin. Nutr. 2009, 63, S5-S21. [CrossRef]

43. Itcho, K.; Yoshii, Y.; Ohno, H.; Oki, K.; Shinohara, M.; Irino, Y.; Toh, R.; Ishida, T.; Hirata, K.; Yoneda, M. Association between Serum Elaidic Acid Concentration and Insulin Resistance in Two Japanese Cohorts with Different Lifestyles. J. Atheroscler. Thromb. 2017, 24, 1206-1214. [CrossRef]

44. Liu, B.; Sun, Y.; Snetselaar, L.G.; Sun, Q.; Yang, Q.; Zhang, Z.; Liu, L.; Hu, F.B.; Bao, W. Association between Plasma Trans-Fatty Acid Concentrations and Diabetes in a Nationally Representative Sample of US Adults. J. Diabetes 2018, 10, 653-664. [CrossRef]

45. Angelieri, C.T.; Barros, C.R.; Siqueira-Catania, A.; Ferreira, S.R.G. Trans fatty acid intake is associated with insulin sensitivity but independently of inflammation. Brazilian J. Med. Biol. Res. 2012, 45, 625-631. [CrossRef] [PubMed]

46. Ishibashi, K.; Nehashi, K.; Oshima, T.; Ohkura, N.; Atsumi, G.-I. Differentiation with Elaidate Tends to Impair Insulin-Dependent Glucose Uptake and GLUT4 Translocation in 3T3-L1 Adipocytes. Int. J. Food Sci. Nutr. 2016, 67, 99-110. [CrossRef] 
47. Zhao, X.; Shen, C.; Zhu, H.; Wang, C.; Liu, X.; Sun, X.; Han, S.; Wang, P.; Dong, Z.; Ma, X.; et al. Trans-Fatty Acids Aggravate Obesity, Insulin Resistance and Hepatic Steatosis in C57BL/6 Mice, Possibly by Suppressing the IRS1 Dependent Pathway. Molecules 2016, 21, 705. [CrossRef]

48. Zhu, W.; Niu, X.; Wang, M.; Li, Z.; Jiang, H.-K.; Li, C.; Caton, S.J.; Bai, Y. Endoplasmic Reticulum Stress May Be Involved in Insulin Resistance and Lipid Metabolism Disorders of the White Adipose Tissues Induced by High-Fat Diet Containing Industrial Trans-Fatty Acids. Diabetes Metab. Syndr. Obes. Targets Ther. 2019, 12, 1625-1638. [CrossRef] [PubMed]

49. Zulyniak, M.A.; Ralston, J.C.; Tucker, A.J.; MacKay, K.A.; Hillyer, L.M.; McNicholas, P.D.; Graham, T.E.; Robinson, L.E.; Duncan, A.M.; Ma, D.W.L.; et al. Vaccenic acid in serum triglycerides is associated with markers of insulin resistance in men. Appl. Physiol. Nutr. Metab. 2012, 37, 1003-1007. [CrossRef]

50. Weir, N.L.; Steffen, B.T.; Guan, W.; Johnson, L.M.; Djousse, L.; Mukamal, K.J.; Tsai, M.Y. Circulating omega-7 fatty acids are differentially related to metabolic dysfunction and incident type II diabetes: The Multi-Ethnic Study of Atherosclerosis (MESA). Diabetes Metab. 2020, 46, 319-325. [CrossRef]

51. Larsen, T.M.; Toubro, S.; Gudmundsen, O.; Astrup, A. Conjugated linoleic acid supplementation for 1 y does not prevent weight or body fat regain. Am. J. Clin. Nutr. 2006, 83, 606-612. [CrossRef] [PubMed]

52. Lambert, E.V.; Goedecke, J.H.; Bluett, K.; Heggie, K.; Claassen, A.; Rae, D.E.; West, S.; Dugas, J.; Dugas, L.; Meltzer, S.; et al. Conjugated linoleic acid versus high-oleic acid sunflower oil: Effects on energy metabolism, glucose tolerance, blood lipids, appetite and body composition in regularly exercising individuals. Br. J. Nutr. 2007, 97, 1001-1011. [CrossRef]

53. Ryder, J.W.; Portocarrero, C.P.; Song, X.M.; Cui, L.; Yu, M.; Combatsiaris, T.; Galuska, D.; Bauman, D.E.; Barbano, D.M.; Charron, M.J.; et al. Isomer-Specific Antidiabetic Properties of Conjugated Linoleic Acid. Diabetes 2001, 50, 1149-1157. [CrossRef] [PubMed]

54. Micha, R.; Mozaffarian, D. Trans fatty acids: Effects on cardiometabolic health and implications for policy. Prostaglandins Leukot. Essent. Fat. Acids 2008, 79, 147-152. [CrossRef]

55. Kummerow, F.A.; Zhou, Q.; Mahfouz, M.M.; Smiricky, M.R.; Grieshop, C.M.; Schaeffer, D.J. Trans fatty acids in hydrogenated fat inhibited the synthesis of the polyunsaturated fatty acids in the phospholipid of arterial cells. Life Sci. 2004, 74, 2707-2723. [CrossRef]

56. Revin, V.V.; Gromova, N.V.; Revina, E.S.; Martynova, M.I.; Seikina, A.I.; Revina, N.V.; Imarova, O.G.; Solomadin, I.N.; Tychkov, A.Y.; Zhelev, N. Role of membrane lipids in the regulation of erythrocytic oxygen-transport function in cardiovascular diseases. Biomed. Res. Int. 2016, 2016. [CrossRef] [PubMed]

57. Khaw, K.T.; Friesen, M.D.; Riboli, E.; Luben, R.; Wareham, N. Plasma phospholipid fatty acid concentration and incident coronary heart disease in men and women: The EPIC-Norfolk prospective study. PLoS Med. 2012, 9. [CrossRef] [PubMed]

58. Flock, M.R.; Kris-Etherton, P.M. Diverse physiological effects of long-chain saturated fatty acids: Implications for cardiovascular disease. Curr. Opin. Clin. Nutr. Metab. Care 2013, 16, 133-140. [CrossRef] [PubMed]

59. Gillman, M.W.; Cupples, L.A.; Gagnon, D.; Millen, B.E.; Ellison, R.C.; Castelli, W.P. Margarine intake and subsequent coronary heart disease in men. Epidemiology 1997, 8, 144-149. [CrossRef]

60. Lindmark Månsson, H. Fatty acids in bovine milk fat. Food Nutr. Res. 2008, 52, 1-4. [CrossRef]

61. Harvey, K.A.; Walker, C.L.; Xu, Z.D.; Whitley, P.; Siddiqui, R.A. Trans fatty acids: Induction of a proinflammatory phenotype in endothelial cells. Lipids 2012, 47, 647-657. [CrossRef]

62. Li, J.; Rao, H.; Bin, Q.; Fan, Y.W.; Li, H.Y.; Deng, Z.Y. Linolelaidic acid induces apoptosis, cell cycle arrest and inflammation stronger than elaidic acid in human umbilical vein endothelial cells through lipid rafts. Eur. J. Lipid Sci. Technol. 2017, 119, 1600374. [CrossRef]

63. Flock, M.R.; Kris-Etherton, P.M. Dietary guidelines for americans 2010: Implications for cardiovascular disease. Curr. Atheroscler. Rep. 2011, 13, 499-507. [CrossRef]

64. Takeuchi, H.; Ito, E.; Tomioka, T.; Tabuchi, E.; Fuhshuku, K.I.; Asano, Y. Trans fatty acid intake and serum cholesterol levels in young japanese women. Biosci. Biotechnol. Biochem. 2012, 76, 1627-1632. [CrossRef]

65. World Health Organization (WHO). Replace Trans Fat: Frequently Asked Questions; World Health Organisation: Geneva, Switzerland, 2018.

66. Stender, S.; Astrup, A.; Dyerberg, J. Ruminant and industrially produced trans fatty acids: Health aspects. Food Nutr. Res. 2008, 52, 1-9. [CrossRef] [PubMed]

67. Baer, D.J.; Judd, J.T.; Clevidence, B.A.; Tracy, R.P. Dietary fatty acids affect plasma markers of inflammation in healthy men fed controlled diets: A randomized crossover study. Am. J. Clin. Nutr. 2004, 79, 969-973. [CrossRef]

68. Oie, E.; Ueland, T.; Dahl, C.P.; Bohov, P.; Berge, C.; Yndestad, A.; Gullestad, L.; Aukrust, P.; Berge, R.K. Fatty acid composition in chronic heart failure: Low circulating levels of eicosatetraenoic acid and high levels of vaccenic acid are associated with disease severity and mortality. J. Intern. Med. 2011, 270, 263-272. [CrossRef]

69. Stampfer, W.C.W.M.J.; Manson, J.E.; Speizer, G.A.C.F.E.; Rosner, B.A.; Hennekens, L.A.S.C.H. Intake of trans fatty acids and risk of coronary heart disease among women. Lancet 1993, 341, 581-585. [CrossRef]

70. Pietinen, P.; Ascherio, A.; Korhonen, P.; Hartman, A.M.; Willett, W.C.; Albanes, D.; Virtamo, J. Intake of fatty acids and risk of coronary heart disease in a cohort of Finnish men. The Alpha-Tocopherol, Beta-Carotene Cancer Prevention Study. Am. J. Epidemiol. 1997, 145, 876-887. [CrossRef] [PubMed] 
71. Bassett, C.M.C.; Edel, A.L.; Patenaude, A.F.; McCullough, R.S.; Blackwood, D.P.; Chouinard, P.Y.; Paquin, P.; Lamarche, B.; Pierce, G.N. Dietary vaccenic acid has antiatherogenic effects in LDLr-/- mice. J. Nutr. 2010, 140, 18-24. [CrossRef] [PubMed]

72. Kim, H.; Jeong, C.H.; Lee, H.G.; Han, S.G. Comparison of trans-fatty acids on proliferation and migration of vascular smooth muscle cells. Food Sci. Biotechnol. 2017, 26, 501-505. [CrossRef]

73. Reynolds, C.M.; Loscher, C.E.; Moloney, A.P.; Roche, H.M. Cis-9, trans-11-conjugated linoleic acid but not its precursor transvaccenic acid attenuate inflammatory markers in the human colonic epithelial cell line Caco-2. Br. J. Nutr. 2008, $100,13-17$. [CrossRef] [PubMed]

74. Derakhshande-Rishehri, S.M.; Mansourian, M.; Kelishadi, R.; Heidari-Beni, M. Association of foods enriched in conjugated linoleic acid (CLA) and CLA supplements with lipid profile in human studies: A systematic review and meta-analysis. Public Health Nutr. 2015, 18, 2041-2054. [CrossRef]

75. Ardisson Korat, A.V.; Chiu, Y.H.; Bertrand, K.A.; Zhang, S.; Epstein, M.M.; Rosner, B.A.; Chiuve, S.; Campos, H.; Giovannucci, E.L.; Chavarro, J.E.; et al. Red blood cell membrane trans fatty acid levels and risk of non-Hodgkin lymphoma: A prospective nested case-control study. Am. J. Clin. Nutr. 2020, 112, 1576-1583. [CrossRef]

76. Yammine, S.; Huybrechts, I.; Biessy, C.; Dossus, L.; Aglago, E.K.; Naudin, S.; Ferrari, P.; Weiderpass, E.; Tjønneland, A.; Louise Hansen, L.; et al. Dietary and Circulating Fatty Acids and Ovarian Cancer Risk in the European Prospective Investigation into Cancer and Nutrition. Cancer Epidemiol. Biomark. Prev. 2020, 29, 1739-1749. [CrossRef]

77. Aglago, E.K.; Murphy, N.; Huybrechts, I.; Nicolas, G.; Casagrande, C.; Fedirko, V.; Weiderpass, E.; Rothwell, J.A.; Dahm, C.C.; Olsen, A.; et al. Dietary intake and plasma phospholipid concentrations of saturated, monounsaturated and trans fatty acids and colorectal cancer risk in the European Prospective Investigation into Cancer and Nutrition cohort. Int. J. Cancer. 2021, 149, 865-882. [CrossRef]

78. Matta, M.; Huybrechts, I.; Biessy, C.; Casagrande, C.; Yammine, S.; Agnès Fournier, A.; Olsen, K.S.; Lukic, M.; Gram, I.T.; Ardanaz, E.; et al. Dietary intake of trans fatty acids and breast cancer risk in 9 European countries. BMC Med. 2021, 19, 81. [CrossRef]

79. Pickens, C.A.; Lane-Elliot, A.; Comstock, S.S.; Fenton, J.I. Altered saturated and monounsaturated plasma phospholipid fatty acid profiles in adult males with colon adenomas. Cancer Epidemiol. Biomark. Prev. 2016, 25, 498-506. [CrossRef] [PubMed]

80. Ohmori, H.; Fujii, K.; Kadochi, Y.; Mori, S.; Nishiguchi, Y.; Fujiwara, R.; Kishi, S.; Sasaki, T.; Kuniyasu, H. Elaidic Acid, a Trans -Fatty Acid, Enhances the Metastasis of Colorectal Cancer. Cells Pathobiol. 2017, 84, 144-151. [CrossRef]

81. Voorrips, L.E.; Brants, H.A.M.; Kardinaal, A.F.M.; Hiddink, G.J.; van den Brandt, P.A.; Alexandra Goldbohm, R. Intake of conjugated linoleic acid, fat, and other fatty acids in relation to postmenopausal breast cancer: The Netherlands Cohort Study on Diet and Cancer. Am. J. Clin. Nutr. 2002, 76, 873-882. [CrossRef]

82. Benjamin, S.; Spener, F. Conjugated linoleic acids as functional food: An insight into their health benefits. Nutr. Metab. 2009, 6, 1-13. [CrossRef] [PubMed]

83. Corl, B.A.; Barbano, D.M.; Bauman, D.E.; Ip, C. cis-9, trans-11 CLA derived endogenously from trans-11 18:1 reduces cancer risk in rats. J. Nutr. 2003, 133, 2893-2900. [CrossRef]

84. Lock, A.L.; Corl, B.A.; Barbano, D.M.; Bauman, D.E.; Ip, C. The anticarcinogenic effect of trans-11 18:1 is dependent on its conversion to cis-9, trans-11 CLA by $\Delta$ 9-desaturase in rats. J. Nutr. 2004, 134, 2698-2704. [CrossRef] [PubMed]

85. Banni, S.; Angioni, E.; Murru, E.; Carta, G.; Melis, M.P.; Bauman, D.; Dong, Y.; Ip, C. Vaccenic acid feeding increases tissue levels of conjugated linoleic acid and suppresses development of premalignant lesions in rat mammary gland. Nutr. Cancer 2001, 41, 91-97. [CrossRef]

86. Lampen, A.; Leifheit, M.; Voss, J.; Nau, H. Molecular and cellular effects of cis-9, trans-11-conjugated linoleic acid in enterocytes: Effects on proliferation, differentiation, and gene expression. Biochim. Biophys. Acta-Mol. Cell Biol. Lipids 2005, 1735, 30-40. [CrossRef]

87. Oh, J.J.; Lee, J.S.; Lim, J.N.; Wang, T.; Kim, S.H.; Lee, H.G. Trans vaccenic acid (trans-11 18:1), a precursor of cis-9, trans-11conjugated linoleic acid, exerts a direct anti-carcinogenic function in T47D breast carcinoma cells. Food Sci. Biotechnol. 2014, 23, 641-646. [CrossRef]

88. Lim, J.N.; Oh, J.J.; Wang, T.; Lee, J.S.; Kim, S.H.; Kim, Y.J.; Lee, H.G. Trans-11 18:1 vaccenic acid (TVA) has a direct anti-carcinogenic effect on MCF-7 human mammary adenocarcinoma cells. Nutrients 2014, 6, 627-636. [CrossRef]

89. Song, J.; Wang, Y.; Fan, X.; Wu, H.; Han, J.; Yang, M.; Lu, L.; Nie, G. Trans-vaccenic acid inhibits proliferation and induces apoptosis of human nasopharyngeal carcinoma cells via a mitochondrial-mediated apoptosis pathway. Lipids Health Dis. 2019, 18, 1-9. [CrossRef] [PubMed]

90. World Cancer Research Fund/American Institute for Cancer Research Worlwide Cancer Data: Global Cancer Statistics for the Most Common Cancers. Available online: https://www.wcrf.org/dietandcancer/worldwide-cancer-data/ (accessed on 14 October 2021).

91. Cho, E.; Smith-Warner, S.A.; Spiegelman, D.; Beeson, W.L.; van den Brandt, P.A.; Colditz, G.A.; Folsom, A.R.; Fraser, G.E.; Freudenheim, J.L.; Giovannucci, E.; et al. Dairy foods, calcium, and colorectal cancer: A pooled analysis of 10 cohort studies. J. Natl. Cancer Inst. 2004, 96, 1015-1022. [CrossRef]

92. Mohammadzadeh, M.; Faramarzi, E.; Mahdavi, R.; Nasirimotlagh, B.; Asghari Jafarabadi, M. Effect of conjugated linoleic acid supplementation on inflammatory factors and matrix metalloproteinase enzymes in rectal cancer patients undergoing chemoradiotherapy. Integr. Cancer Ther. 2013, 12, 496-502. [CrossRef] 
93. Aro, A.; Männistö, S.; Salminen, I.; Ovaskainen, M.L.; Kataja, V.; Uusitupa, M. Inverse association between dietary and serum conjugated linoleic acid and risk of breast cancer in postmenopausal women. Nutr. Cancer 2000, 38, 151-157. [CrossRef] [PubMed]

94. Dong, J.Y.; Zhang, L.; He, K.; Qin, L.Q. Dairy consumption and risk of breast cancer: A meta-analysis of prospective cohort studies. Breast Cancer Res. Treat. 2011, 127, 23-31. [CrossRef]

95. den Hartigh, L.J. Conjugated linoleic acid effects on cancer, obesity, and atherosclerosis: A review of pre-clinical and human trials with current perspectives. Nutrients 2018, 11, 370. [CrossRef]

96. Han, S.N.; Leka, L.S.; Lichtenstein, A.H.; Ausman, L.M.; Schaefer, E.J.; Meydani, S.N. Effect of hydrogenated and saturated, relative to polyunsaturated, fat on immune and inflammatory responses of adults with moderate hypercholesterolemia. J. Lipid Res. 2002, 43, 445-452. [CrossRef]

97. López-Plaza, B.; Bermejo, L.M.; Weber, T.K.; Parra, P.; Serra, F.; Hernández, M.; Milla, S.P.; Gómez-Candela, C. Efecto de una suplementación láctea con ácido linoleico conjugado sobre el control de peso y la composición corporal de personas sanas con sobrepeso. Nutr. Hosp. 2013, 28, 2090-2098. [CrossRef]

98. Steck, S.E.; Chalecki, A.M.; Miller, P.; Conway, J.; Austin, G.L.; Hardin, J.W.; Albright, C.D.; Thuillier, P. Conjugated linoleic acid supplementation for twelve weeks increases lean body mass in obese humans. J. Nutr. 2007, 137, 1188-1193. [CrossRef]

99. Hirata, Y.; Takahashi, M.; Kudoh, Y.; Kano, K.; Kawana, H.; Makide, K.; Shinoda, Y.; Yabuki, Y.; Fukunaga, K.; Aoki, J.; et al. Trans-Fatty acids promote proinflammatory signaling and cell death by stimulating the apoptosis signal-regulating kinase 1 (ASK1)-p38 pathway. J. Biol. Chem. 2017, 292, 8174-8185. [CrossRef] [PubMed]

100. Mazidi, M.; Gao, H.K.; Shivappa, N.; Wirth, M.D.; Hebert, J.R.; Kengne, A.P. The relationship of plasma Trans fatty acids with dietary inflammatory index among US adults. Lipids Health Dis. 2017, 16, 1-6. [CrossRef] [PubMed]

101. Higashimura, Y.; Tanaka, Y.; Takagi, T.; Uchiyama, K.; Mizushima, K.; Niki, E.; Naito, Y. Trans-unsaturated fatty acid activates NLRP3 inflammasome in macrophages and exacerbates intestinal inflammation in mice. Biochem. Biophys. Res. Commun. 2020, 529, 243-250. [CrossRef]

102. Monguchi, T.; Hara, T.; Hasokawa, M.; Nakajima, H.; Mori, K.; Toh, R.; Irino, Y.; Ishida, T.; Hirata, K.I.; Shinohara, M. Excessive intake of trans fatty acid accelerates atherosclerosis through promoting inflammation and oxidative stress in a mouse model of hyperlipidemia. J. Cardiol. 2017, 70, 121-127. [CrossRef]

103. Hu, S.B.; Zou, Q.; Lv, X.; Zhou, R.L.; Niu, X.; Weng, C.; Chen, F.; Fan, Y.W.; Deng, Z.Y.; Li, J. 9t18:1 and 11t18:1 activate the MAPK pathway to regulate the expression of PLA2 and cause inflammation in HUVECs. Food Funct. 2020, 11, 649-661. [CrossRef] [PubMed]

104. Smit, L.A.; Katan, M.B.; Wanders, A.J.; Basu, S.; Brouwer, I.A. A high intake of trans fatty acids has little effect on markers of inflammation and oxidative stress in humans. J. Nutr. 2011, 141, 1673-1678. [CrossRef]

105. Gebauer, S.K.; Destaillats, F.; Dionisi, F.; Krauss, R.M.; Baer, D.J. Vaccenic acid and trans fatty acid isomers from partially hydrogenated oil both adversely affect LDL cholesterol: A double-blind, randomized controlled trial. Am. J. Clin. Nutr. 2015, 102, 1339-1346. [CrossRef] [PubMed]

106. Lee, J.S.; Lim, J.N.; Wang, T.; Lee, S.B.; Hwang, J.H.; Jung, U.S.; Kim, M.J.; Choi, S.H.; Ishizuka, S.; Lee, H.G. Physiological concentrations of trans-11 18:1 vaccenic acid suppress pro-inflammatory markers under acute inflammation in isolated ICR mice splenocytes. Food Sci. Biotechnol. 2016, 25, 275-281. [CrossRef]

107. Da Silva, M.S.; Julien, P.; Bilodeau, J.F.; Barbier, O.; Rudkowska, I. Trans Fatty Acids Suppress TNF- $\alpha$-Induced Inflammatory Gene Expression in Endothelial (HUVEC) and Hepatocellular Carcinoma (HepG2) Cells. Lipids 2017, 52, 315-325. [CrossRef]

108. Da Silva, M.S.; Bilodeau, J.F.; Larose, J.; Greffard, K.; Julien, P.; Barbier, O.; Rudkowska, I. Modulation of the biomarkers of inflammation and oxidative stress by ruminant trans fatty acids and dairy proteins in vascular endothelial cells (HUVEC). Prostaglandins Leukot. Essent. Fat. Acids 2017, 126, 64-71. [CrossRef]

109. Jaudszus, A.; Jahreis, G.; Schlörmann, W.; Fischer, J.; Kramer, R.; Degen, C.; Rohrer, C.; Roth, A.; Gabriel, H.; Barz, D.; et al. Vaccenic acid-mediated reduction in cytokine production is independent of $\mathrm{c} 9, \mathrm{t} 11-\mathrm{CLA}$ in human peripheral blood mononuclear cells. Biochim. Biophys. Acta-Mol. Cell Biol. Lipids 2012, 1821, 1316-1322. [CrossRef]

110. Li, J.; Hu, S.B.; He, Y.M.; Zhuo, C.F.; Zhou, R.L.; Chen, F.; Li, H.Y.; Deng, Z.Y. 9c11tCLA modulates 11t18:1 and 9t18:1 induced inflammations differently in human umbilical vein endothelial cells. Sci. Rep. 2018, 8, 1-12. [CrossRef]

111. Pranger, I.G.; Muskiet, F.A.J.; Kema, I.P.; Singh-Povel, C.; Bakker, S.J.L. Potential biomarkers for fat from dairy and fish and their association with cardiovascular risk factors: Cross-sectional data from the LifeLines Biobank and Cohort Study. Nutrients 2019, 11, 1099. [CrossRef] [PubMed]

112. Verneque, B.J.F.; Machado, A.M.; de Abreu Silva, L.; Lopes, A.C.S.; Duarte, C.K. Ruminant and industrial trans-fatty acids consumption and cardiometabolic risk markers: A systematic review. Crit. Rev. Food Sci. Nutr. 2020, 1-11. [CrossRef] [PubMed]

113. Aminot-Gilchrist, D.V.; Anderson, H.D.I. Insulin resistance-associated cardiovascular disease: Potential benefits of conjugated linoleic acid. Am. J. Clin. Nutr. 2004, 79, 1159-1163. [CrossRef] [PubMed]

114. Chichlowski, M.W.; Schroeder, J.W.; Park, C.S.; Keller, W.L.; Schimek, D.E. Altering the fatty acids in milk fat by including canola seed in dairy cattle diets. J. Dairy Sci. 2005, 88, 3084-3094. [CrossRef]

115. Belury, M.A. Dietary conjugated linoleic acid in health: Physiological effects and mechanisms of action. Annu. Rev. Nutr. 2002, 22, 505-531. [CrossRef]

116. Mazidi, M.; Banach, M.; Kengne, A.P. Association between plasma trans fatty acids concentrations and leucocyte telomere length in US adults. Eur. J. Clin. Nutr. 2018, 72, 581-586. [CrossRef] [PubMed] 
117. Wang, S.; Tian, W.; Liu, Y.; Yan, G.; Fang, S.; Wang, Y.; Yu, B. Temporal trend of circulating trans-fatty acids and risk of long-term mortality in general population. Clin. Nutr. 2021, 40, 1095-1101. [CrossRef] [PubMed]

118. Howard, F.A.C.; Henderson, C. Hydrogenation of polyunsaturated fatty acids by human colonic bacteria. Lett. Appl. Microbiol. 1999, 29, 193-196. [CrossRef]

119. Farnworth, E.R.; Chouinard, Y.P.; Jacques, H.; Venkatramanan, S.; Maf, A.A.; Defnoun, S.; Jones, P.J.H. The effect of drinking milk containing conjugated linoleic acid on fecal microbiological profile, enzymatic activity, and fecal characteristics in humans. Nutr. J. 2007, 6, 1-9. [CrossRef]

120. den Hartigh, L.J.; Gao, Z.; Goodspeed, L.; Wang, S.; Das, A.K.; Burant, C.F.; Chait, A.; Blaser, M.J. Obese mice losing weight due to trans-10,cis-12 conjugated linoleic acid supplementation or food restriction harbor distinct gut microbiota. J. Nutr. 2018, 148, 562-572. [CrossRef]

121. Li, H.; Zhuang, P.; Zhang, Y.; Shou, Q.; Lu, Y.; Wang, G.; Qiu, J.; Wang, J.; He, L.; Chen, J.; et al. Mixed Conjugated Linoleic Acid Sex-dependently Reverses High-fat Diet-induced Insulin Resistance via the Gut-adipose Axis. FASEB J. 2021, 35, e21466. [CrossRef]

122. Marques, T.M.; Wall, R.; O’Sullivan, O.; Fitzgerald, G.F.; Shanahan, F.; Quigley, E.M.; Cotter, P.D.; Cryan, J.F.; Dinan, T.G.; Ross, R.P.; et al. Dietary trans-10, cis-12-conjugated linoleic acid alters fatty acid metabolism and microbiota composition in mice. Br. J. Nutr. 2015, 113, 728-738. [CrossRef] [PubMed]

123. Reeves, A.E.; Koenigsknecht, M.J.; Bergin, I.L.; Young, V.B. Suppression of Clostridium difficile in the gastrointestinal tracts of germfree mice inoculated with a murine isolate from the family Lachnospiraceae. Infect. Immun. 2012, 80, 3786-3794. [CrossRef]

124. Bajaj, J.S.; Ridlon, J.M.; Hylemon, P.B.; Thacker, L.R.; Heuman, D.M.; Smith, S.; Sikaroodi, M.; Gillevet, P.M. Linkage of gut microbiome with cognition in hepatic encephalopathy. Am. J. Physiol.-Gastrointest. Liver Physiol. 2012, 302, 168-175. [CrossRef]

125. Zhang, C.; Zhang, M.; Wang, S.; Han, R.; Cao, Y.; Hua, W.; Mao, Y.; Zhang, X.; Pang, X.; Wei, C.; et al. Interactions between gut microbiota, host genetics and diet relevant to development of metabolic syndromes in mice. ISME J. 2010, 4, 232-241. [CrossRef] [PubMed]

126. Chen, Y.; Yang, B.; Ross, R.P.; Jin, Y.; Stanton, C.; Zhao, J.; Zhang, H.; Chen, W. Orally Administered CLA Ameliorates DSS-Induced Colitis in Mice via Intestinal Barrier Improvement, Oxidative Stress Reduction, and Inflammatory Cytokine and Gut Microbiota Modulation. J. Agric. Food Chem. 2019, 67, 13282-13298. [CrossRef] [PubMed]

127. Ge, Y.; Liu, W.; Tao, H.; Zhang, Y.; Liu, L.; Liu, Z.; Qiu, B.; Xu, T. Effect of industrial trans-fatty acids-enriched diet on gut microbiota of C57BL/6 mice. Eur. J. Nutr. 2019, 58, 2625-2638. [CrossRef] [PubMed]

128. Ijssennagger, N.; van der Meer, R.; van Mil, S.W.C. Sulfide as a Mucus Barrier-Breaker in Inflammatory Bowel Disease? Trends Mol. Med. 2016, 22, 190-199. [CrossRef]

129. Del Chierico, F.; Nobili, V.; Vernocchi, P.; Russo, A.; De Stefanis, C.; Gnani, D.; Furlanello, C.; Zandonà, A.; Paci, P.; Capuani, G.; et al. Gut microbiota profiling of pediatric nonalcoholic fatty liver disease and obese patients unveiled by an integrated meta-omics-based approach. Hepatology 2017, 65, 451-464. [CrossRef]

130. Zeng, H.; Liu, J.; Jackson, M.I.; Zhao, F.Q.; Yan, L.; Combs, G.F. Fatty liver accompanies an increase in lactobacillus species in the hind gut of C57BL/ 6 mice fed a high-fat diet. J. Nutr. 2013, 143, 627-631. [CrossRef]

131. Li, C.; Zhang, Y.; Ge, Y.; Qiu, B.; Zhang, D.; Wang, X.; Liu, W.; Tao, H. Comparative transcriptome and microbiota analyses provide new insights into the adverse effects of industrial trans fatty acids on the small intestine of C57BL/6 mice. Eur. J. Nutr. 2021, 60, 975-987. [CrossRef] [PubMed]

132. Carvalho, G.C.B.C.; Moura, C.S.; Roquetto, A.R.; Barrera-Arellano, D.; Yamada, A.T.; dos Santos, A.; Saad, M.J.A.; Amaya-Farfan, J. Impact of Trans-Fats on Heat-Shock Protein Expression and the Gut Microbiota Profile of Mice. J. Food Sci. 2018, 83, 489-498. [CrossRef]

133. Awadel-Kariem, F.M.; Patel, P.; Kapoor, J.; Brazier, J.S.; Goldstein, E.J.C. First report of Parabacteroides goldsteinii bacteraemia in a patient with complicated intra-abdominal infection. Anaerobe 2010, 16, 223-225. [CrossRef]

134. Ulger Toprak, N.; Bozan, T.; Birkan, Y.; Isbir, S.; Soyletir, G. Butyricimonas virosa: The first clinical case of bacteraemia. New Microbes New Infect. 2015, 4, 7-8. [CrossRef]

135. Depommier, C.; Everard, A.; Druart, C.; Plovier, H.; Van Hul, M.; Vieira-Silva, S.; Falony, G.; Raes, J.; Maiter, D.; Delzenne, N.M.; et al. Supplementation with Akkermansia muciniphila in overweight and obese human volunteers: A proof-of-concept exploratory study. Nat. Med. 2019, 25, 1096-1103. [CrossRef] [PubMed]

136. Hua, Y.; Fan, R.; Zhao, L.; Tong, C.; Qian, X.; Zhang, M.; Xiao, R.; Ma, W. Trans -Fatty Acids Alter the Gut Microbiota in High-Fat-Diet-Induced Obese Rats. Br. J. Nutr. 2020, 124, 1251-1263. [CrossRef] [PubMed]

137. Okamura, T.; Hashimoto, Y.; Majima, S.; Senmaru, T.; Ushigome, E.; Nakanishi, N.; Asano, M.; Yamazaki, M.; Takakuwa, H.; Hamaguchi, M.; et al. Trans Fatty Acid Intake Induces Intestinal Inflammation and Impaired Glucose Tolerance. Front. Immunol. 2021, 12, 669672. [CrossRef] [PubMed]

138. Stender, S.; Astrup, A.; Dyerberg, J. Tracing artificial trans fat in popular foods in Europe: A market basket investigation. BMJ Open 2014, 4, 1-8. [CrossRef]

139. European Heart Network European Cardiovascular Disease Statistics: 2017 Edition. Available online: https://ehnheart.org/cvdstatistics/cvd-statistics-2017.html (accessed on 14 October 2021).

140. World Health Organisation (WHO); International Agency for Research on Cancer (IARC). REPLACE Trans Fat: An Action Package to Eliminate Industrially Produced Trans-Fatty Acids: Module 1: Review; World Health Organisation: Geneva, Switzerland, 2020. 
141. European Food Safety Autority (EFSA). Scientific and technical assistance on trans fatty acids. EFSA Support. Publ. 2018, 15, 1433e. [CrossRef]

142. Institute of Medicine (IOM). Dietary Reference Intakes for Energy, Carbohydrate, Fiber, Fat, Fatty Acids, Cholesterol, Protein and Amino Acids; The National Academies Press: Washington, DC, USA, 2005.

143. PAHO/WHO. Plan of Action for The Elimination of Industrially Produced Trans-Fatty Acids: PAHO 2020-2025; Pan American Health Organization: Washington DC, USA, 2020; Volume 2017.

144. World Health Organization (WHO). Global database on the Implementation of Nutrition Action (GINA). TFA Country Score Card. Available online: https:/ / extranet.who.int/nutrition/gina/en/scorecard/TFA (accessed on 14 October 2021).

145. Customs Union. Technical Regulation on Fat and Oil Products; Custom Union: Moscow, Russia, 2013.

146. European Commission (EU). Regulation (EU) No 1169/2011 of the European Parliament and of the Council of 25 October 2011. Off. J. Eur. Union 2011, 304/18, 46. [CrossRef]

147. European Commission (EU). Commission Regulation Amending Annex III to Regulation (EC) No 1925/2006 of the European Parliament and of the Council as Regards Trans Fat, Other than Trans Fat Naturally Occurring in Fat of Animal Origin; Official Journal of the European Union: Brussels, Belgium, 2019.

148. Astiasarán, I.; Abella, E.; Gatta, G.; Ansorena, D. Margarines and fast-food French fries: Low content of trans fatty acids. Nutrients 2017, 9, 662. [CrossRef]

149. Menaa, F.; Menaa, A.; Tréton, J.; Menaa, B. Technological approaches to minimize industrial trans fatty acids in foods. J. Food Sci. 2013, 78, 377-386. [CrossRef]

150. World Health Organization (WHO). Eliminating Trans Fats in Europe: A Policy Brief; WHO Regional Office for Europe: Copenhagen, Denmark, 2015.

151. World Health Organization (WHO). Salt and Trans-Fats Assessed in Kyrgyz Republic with WHO Support. Available online: https:/ / www.euro.who.int/en/countries/kyrgyzstan/news/news/2016/11/salt-and-trans-fats-assessed-in-kyrgyzrepublic-with-who-support (accessed on 14 October 2021).

152. Stender, S.; Dyerberg, J.; Bysted, A.; Leth, T.; Astrup, A. A trans world journey. Atheroscler. Suppl. 2006, 7, 47-52. [CrossRef] 